Please cite this article as: C. Arkar, T. Žižak, S. Domjan, S. Medved: Dynamic parametric models for the holistic evaluation of semi-transparent photovoltaic/thermal façade with latent storage inserts, Applied Energy, 280

(2020) 115994, https://doi.org/10.1016/j.apenergy.2020.115994

NOTE: This is a PDF file of an unedited manuscript that has been accepted for publication to Applied Energy. Therefore, the information contained in this manuscript may change before publication.

\title{
Dynamic parametric models for the holistic evaluation of semi-transparent photovoltaic/thermal façade with latent storage inserts
}

\author{
C. Arkar, T. Žižak, S. Domjan, S. Medved* \\ University of Ljubljana, Faculty of Mechanical Engineering, Laboratory for Sustainable \\ Technologies in Buildings, Aškerčeva 6, Ljubljana 1000, Slovenia \\ * Corresponding author: saso.medved@fs.uni-lj.si
}

\begin{abstract}
High energy efficiency, energy autonomy, and improved living conditions are basic requirements of sustainable buildings. Advanced building envelope structures can provide these requirements. In the present paper, multipurpose façade structure designed as semi-transparent modular building-integrated photovoltaic façade with a forced ventilated cavity and enhanced heat storage capacity, using encapsulated phase change inserts installed on inner glass pane of photovoltaic module and on building envelope, is evaluated. The design of the façade structure, including simultaneous optimization of photovoltaic cell-packing factor, phase change material inserts properties, and heat transfer by convection in air gap, was based on transient modeling. A $60 \%$ photovoltaic cell-packing factor enables the highest overall energy efficiency, while phase change material inserts on the inner glass pane of photovoltaic module have no impact on diurnal photovoltaic cell efficiency. However, a phase change material layer installed on the envelope decreases the diurnal heat losses by half at solar radiation of $2200 \mathrm{Wh} / \mathrm{m}^{2}$ day. The energy performance of an optimized modular structure was determined via in-situ experiments; the data were used for developing dynamic approximation models of energy efficiency indicators. It was found that multiple regression models with interactions and past values can predict dynamic responses with sufficient accuracy. Depending on the heating season's climate conditions, the developed semi-transparent modular building-integrated photovoltaic façade decreases the energy needs $40 \%$ to $55 \%$ in comparison to the reference façade with solar energy utilization efficiency in the range between $44 \%$ and $63 \%$. This proves that such structures can contribute to fulfilling of requirements of sustainable buildings.
\end{abstract}

Keywords: In-situ experiments, building-integrated photovoltaics façade structures, PCM solar storage, dynamic thermal insulation, multi-parametric regression models

\section{Nomenclature}

\begin{tabular}{|l|l|}
\hline a, b & regression model coefficients \\
\hline$c_{p}$ & specific heat capacity $(\mathrm{kJ} / \mathrm{kgK})$ \\
\hline E & electricity power $(\mathrm{W})$ \\
\hline $\mathrm{G}$ & solar irradiation $\left(\mathrm{W} / \mathrm{m}^{2}\right)$ \\
\hline
\end{tabular}




\begin{tabular}{|l|l|}
\hline $\mathrm{h}$ & surface heat transfer coefficient $\left(\mathrm{W} / \mathrm{m}^{2} \mathrm{~K}\right)$, height \\
\hline $\mathrm{H}$ & diurnal solar radiation $\left(\mathrm{kWh} / \mathrm{m}^{2} \mathrm{~d}\right)$ \\
\hline $\mathrm{K}_{\mathrm{T}}$ & temperature correction factor $(-)$ \\
\hline $\mathrm{M}$ & measured values in statistical indicators \\
\hline $\mathrm{n}$ & number of measured data \\
\hline$\dot{\mathrm{q}}$ & specific heat flux $\left(\mathrm{W} / \mathrm{m}^{2}\right)$ \\
\hline$\hat{\mathrm{q}}$ & amplitude of diurnal heat flux $\left(\mathrm{W} / \mathrm{m}^{2}\right)$ \\
\hline$\dot{\mathrm{Q}}$ & heat flux $(\mathrm{W})$ \\
\hline $\mathrm{Q}^{2}$ & heat $(\mathrm{Wh})$ \\
\hline $\mathrm{Q}^{\prime} \Delta \mathrm{U}$ & virtual heat gains due to decreased thermal transmittance $(\mathrm{Wh})$ \\
\hline $\mathrm{P}$ & predicted values in statistical indicators \\
\hline $\mathrm{p}$ & number of adjustable model parameters \\
\hline $\mathrm{Ra}$ & color rendering index $(-)$ \\
\hline $\mathrm{t}$ & time $(\mathrm{h})$ \\
\hline $\mathrm{T}$ & temperature $\left({ }^{\circ} \mathrm{C}\right)$ \\
\hline $\mathrm{U}$ & static thermal transmittance $\left(\mathrm{W} / \mathrm{m}^{2} \mathrm{~K}\right)$ \\
\hline $\mathrm{U}_{\text {eff }}$ & dynamic thermal transmittance $\left(\mathrm{W} / \mathrm{m}^{2} \mathrm{~K}\right)$ \\
\hline $\mathrm{v}$ & velocity $(\mathrm{m} / \mathrm{s})$ \\
\hline$\dot{\mathrm{V}}$ & air flow rate $\left(\mathrm{m}^{3} / \mathrm{h}\right)$ \\
\hline $\mathrm{x}$ & independent variable \\
\hline $\mathrm{y}$ & dependent variable \\
\hline$\beta$ & temperature coefficient $(\% / \mathrm{K})$ \\
\hline$\varepsilon_{\mathrm{v}}$ & air preheating efficiency $(-)$ \\
\hline$\lambda$ & thermal conductivity $(\mathrm{W} / \mathrm{mK})$ \\
\hline$\eta$ & efficiency $(\%)$ \\
\hline & \\
\hline
\end{tabular}

\section{Subscript}

\begin{tabular}{|l|l|}
\hline a & air \\
\hline avg & average \\
\hline BIPV,4 & BIPV fourth row \\
\hline BIPV,6 & BIPV sixth row \\
\hline corr & correction \\
\hline c + r & combined convection and radiation \\
\hline d & daily \\
\hline e & outdoor \\
\hline exp & experimental \\
\hline g & glass \\
\hline glob, 90 & global on vertical surface \\
\hline i & in, numerator \\
\hline num & numerical \\
\hline occ & occupied hours \\
\hline PV & PV cells \\
\hline ref & reference \\
\hline si & inner surface of glass \\
\hline sol & solar \\
\hline v & ventilation \\
\hline
\end{tabular}

\section{Introduction}

Trends in sustainable development, based on international agreements, such as the Paris Climate Agreement [1] or environment policy actions, like The European Green Deal [2], compel scientists and 
engineers to find solutions for the more rational use of natural resources and technologies for decreasing emissions of all kinds of pollutants. As building stock is responsible for a substantial share of greenhouse gas emissions and approximately $40 \%$ of final energy use [2], significant performance improvement of new and renovated buildings will be required to fulfill the goals of those actions. The Recast of Energy Performance of Building Directive [3] introduces requirements for nearly Zero Energy Buildings as buildings with low primary energy demand and high shares of the utilization of (local) renewable energy sources. The final goal is energy self-sufficient buildings. The utilization of solar energy with photovoltaic systems is assumed to be one of the most promising opportunities, especially in the urban environment [4]. Photovoltaic systems in the form of building-integrated PV modules are great business opportunities for greener cities [5]. Possible energy savings of integrating photovoltaics in buildings have been well researched, estimating up to $30 \%$ savings of the total annual HVAC energy consumption in Los Angeles [6]; Defaix et al. [7] stated that up to $22 \%$ of total electricity consumption could be covered with BIPV implementation in buildings in the EU-27 countries.

BIPV system transforms buildings from energy consumers to energy producers [8]. In comparison to non-integrated PV systems, BIPV systems can additionally provide weather and noise protection, daylighting, waterproofing, reduced thermal transmittance, and reduced system costs. The review of BIPV technology presented by Shukla et al. [8] showed that in the current BIPV market only $20 \%$ of BIPV installations are façade structures; the remaining $80 \%$ are rooftop mounted.

BIPV in the form of ventilated building envelope structures combines the benefits of a PV system and a solar thermal system. As summarized in [9], such a BIPV system allows achieving the most efficient operation of the PV module from both electricity generation and solar air heating, thus considerably improving solar energy utilization. BIPV systems that combine power and heat generation are classified as building-integrated photovoltaic thermal (BIPV/T) systems [10]. Although BIPV/T structures can be designed as hydraulic systems [11], the applications for the heating of air are more common and have advantages as low exergy applications [12]. In addition to the generation of heat, the ventilation of the BIPV/T reduces overheating of the PV cells, which leads to increased PV cell efficiency. The cooling of the PV cell potentially increases the lifetime of the PV module [13]. Peng et al. [14] have made an experimental BIPV setup with a-Si PV cells with $0.4 \mathrm{~m}$ width air gap. An increase of $1.9 \%$ of total daily energy production was observed with natural ventilation compared to no ventilation and an additional increase of 3\% with forced ventilation. Kaiser et al. [15] have studied the effect of forced ventilation on PV cell efficiency in BIPV structure. An increase of peak power output of $19 \%$ at $1000 \mathrm{~W} / \mathrm{m}^{2}$ irradiance at air velocity in an air gap at $6 \mathrm{~m} / \mathrm{s}$ compared to a naturally ventilated air gap $(0.5 \mathrm{~m} / \mathrm{s})$ was observed.

The PV cell temperature also depends on the PV cell packing factor, which is the percentage of the PV module covered by opaque PV cells. In this way, a semi-transparent BIPV (s- $\tau$ BIPV) is formed. s- $\tau$ BIPVs enable solar gains and daylighting, and have a positive effect on PV cell temperature. The transparency can be provided by thin-film PV cells [16-19] or with suitable packing factor. Later enables at least partial unobstructed view towards outdoor which is important feature in building wellbeing assessment and high value of Color Rendering Index (Ra). Research conducted on a single-glazed s- $\tau$ BIPV façade [20] showed that the PV cell temperature was $7{ }^{\circ} \mathrm{C}$ higher in the case of an $80 \%$ packing factor compared to a $10 \%$ packing factor, which corresponds to 5.5\% lower PV cell efficiency. Semitransparent BIPV/Ts increase solar energy utilization. Yang and Athienitis [21] experimentally evaluated opaque and semi-transparent BIPV/T systems, with the same $80 \%$ packing factor. They found that s- $\tau$ BIPV/Ts have a $7.6 \%$ higher thermal efficiency due to the absorption of solar radiation at the back surface of the cavity. Hu et al. [22] also report that solar energy utilization efficiency increases with the ventilation of the air gap in the case of double-sided heated surfaces. By ventilation of the air cavity, transmission heat losses of the façade structure can be utilized, acting as dynamic thermal insulation [23]. Fantucci et al. [24] analyzed preheating ventilation efficiency with test chamber experiments, thus neglecting the solar radiation effect. Preheating efficiency between $9 \%$ and $20 \%$ was achieved. 
Commonly, researchers report that cooling with latent heat storage improves the annual electricity production with PV and that such measures are also cost effective [25]. A literature review [26] reveals that PCM heat storage is most often placed on the backside of a BIPV. Indartono et al. [27] used a 15 mm PCM layer with a PCM melting temperature range of $42-55^{\circ} \mathrm{C}$ on the backside of a PV module. They achieved $6 \%$ and $21.2 \%$ higher daily electrical efficiencies compared to a PV module without PCM heat storage in the case of a free-standing PV module and an unventilated PV module on a roof, respectively. Kant et al. [28] conducted a numerical study of forced-ventilated BIPV and optimized PCM thickness, air gap widths, and mass flow rates of ventilation air according to PV module temperature and heat extracted with ventilation air. The authors report that maximum heat transfer for the air was established with a gap width of $0.08 \mathrm{~m}$ and a ventilation air flow rate of $0.091 \mathrm{~kg} / \mathrm{s}$. They conclude that PCM installed on the PV module decreases the amount of heat transferred by the air; nevertheless, they did not analyze the decreases of heat flux amplitude and time lag. In a recent study, Čurpek and Čekon [29] used commercial PCM RT27 on a BIPV ventilated façade to decrease PV cell temperature. The results reveal lower PV module temperatures in the hours until solar noon while PV module while temperatures in the afternoon hours exceed the temperatures of PV module without PCM. Research by Japs et al. [30] also reports the negative impact of PCM on the cooling of PV module due to the low thermal conductivity of PCM.

The impact of PCM storage on the internal wall of the BIPV ventilated façade was studied by Aelenei et al. [31]. They report a total solar efficiency of $20 \%$, including electricity production and heat gains through wall and ventilation air. In their further research [12], they optimize the PCM board thickness $(0.04 \mathrm{~m})$ and air cavity width $(0.08 \mathrm{~m})$ and the air flow rate $(9 \mathrm{~m} / \mathrm{s})$ and report the total solar energy utilization efficiency of 64\%. However, such high air flow rates are questionable in BIPV applications due to high pressure drop and possible noise emissions.

The energy performance evaluation of BIPV/T and the performance metric can be based on numerical modeling or in-situ evaluation. For engineering practice, both approaches are time-consuming and require deep knowledge and experience; nevertheless, they can be used for developing the empirical models with which the evaluation of energy performance can be approximated with sufficient accuracy for professional purposes. The multiple linear regression model presented by Trigo-Gonzales et al. [32] enables the determination of hourly PV production for different PV technologies. Kaiser et al. [15], in addition to an empirical model of PV cell temperature, presents empirical correlations for the power and electrical efficiency for forced ventilated BIPV modules, which can be used for performance prediction. The review and validation of several simplified and detailed BIPV thermal models, presented in [33], show good agreement of numerical and experimental results, including for linear regression models with solar radiation as the only independent variable. Empirical models for diurnal solar energy utilization by BIPV, preheating of the ventilation air, and heat gains of the façade wall are developed by Domjan et al. [34]. The statistical indicators of the Normalized Mean Bias Error (NMBE) of 2.4\% and 1.4\% were obtained for the developed models. The review of the literature has shown that hour-to-hour regression models for the dynamic modeling of energy performance indicators, as well as solar energy utilization with s- $\tau$ BIPV/T, forced ventilated structures are not available.

This paper presents the process of the determination of impact of construction parameters, the design, experimental assessment and characterization of modular semi-transparent BIPV/T façade structure with a double-sided, solar-heated, forced-ventilated cavity with integrated latent heat storage. The research was performed in four phases: i) using CFD techniques and in-situ experiments, the design of modular s- $\tau$ BIPV/T was done, including determination of geometry, the defining of the PV cell-packing factor and the evaluation of the impact of PCM inserts, ii) the thermal response and dynamic energy balance of optimized prototype s- $\tau$ BIPV/T structure was monitored in-situ during the whole heating period, iii) experiment data were used to determine diurnal energy efficiency indicators including effective thermal transmittance, the efficiency of preheating of air for space ventilation and the amplitude of heat flux on the inner surface of the façade structure (towards building interior), iv) linear dynamic (hourly) regression models of energy efficiency indicators were developed based on 
experimental data by statistical evaluation and validated for selected days during the in-situ experiment, v) a case study of energy balance evaluation of a prototype s- $\tau$ BIPV/T was performed for selected climate conditions.

To the best of the authors' knowledge, the following novelties addressed in the presented article can be pointed out: a) results from a study of the impact of PV cell cooling with forced air ventilation and latent heat storage was investigated for a specific case of PV cells encapsulation between (thick) glass layers of a BIPV glazed façade structure, b) heat transfer in a double-sided heated air solar collector used for the preheating of ventilation air was investigated numerically to define the optimum PV cell-packing factor and evaluated in the heating season using long in-situ experiments, c) description of the development of most appropriate dynamic (hourly) approximation models with definitions of impact parameters on each of energy efficiency indicator are shown.

\section{Object and goals of the research}

A prototype BIPV façade structure was designed as q modular unit taking into account multifunctional properties, possible use in the renovation of buildings and the possibility of combination with all-glass BIPV façade structures, which are built as semi-transparent in order to provide daylight to indoor spaces and the view of the occupants toward the exterior. The prototype has three parts: the semi-transparent glazed BIPV structure with monocrystalline PV cells, a forced ventilated air gap with a bottom opening, and supply openings on the top of the air gap and double-layer PCM latent storage with high solar absorptivity coating; it was designed to improve the energy efficiency of buildings during the heating season. The prototype was installed on a light-weight composite wall made of two layers of laminated wood with thermal insulation between them. The composite wall has static thermal transmittance $\mathrm{U}$ $1.027 \mathrm{~W} / \mathrm{m}^{2} \mathrm{~K}$. Through those components, it was expected that a) electricity production will increase due to cooling by the air in the forced-ventilated air gap and the PCM inserts installed on the glass behind the PV cell, b) ventilation air will be preheated in the double-sided solar-heated air gap to such an extent that decentralized ventilation will provide heat gains similar to centralized mechanical ventilation with heat recovery, c) dynamic diurnal thermal transmittance of the façade structure will be close to the adequately thermally insulated opaque wall, which will be a significant benefit in case of building renovation, and d) solar heat latent storage will improve the dynamic thermal response of the façade by decreasing the amplitude of heat flux transferring into the interior, which will also potentially improve the indoor thermal comfort. In the phase of prototype development, all functionalities were evaluated with the numerical modeling of transient thermal response using CFD techniques. When the first step of modeling was finished, the prototype was built (Fig. 1) and in-situ measuring data were used to confirm some of the decisions made during numerical modeling. The area of the prototype BIPV/T structure is $0.508 \mathrm{~m}^{2}(1.167 \mathrm{~m} \times 0.437 \mathrm{~m})$. 

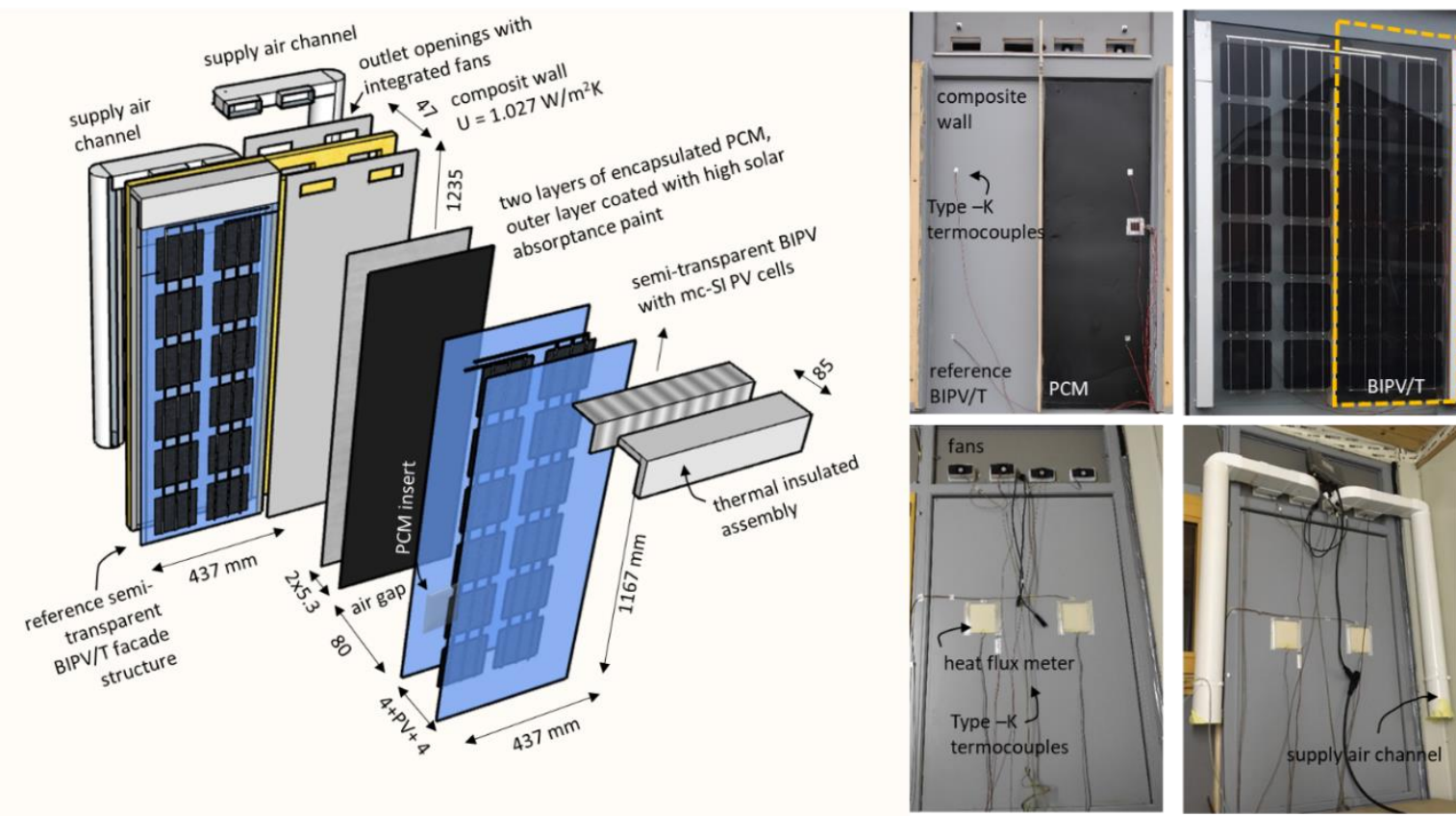

Fig. 1. Prototype of semi-transparent BIPV/T façade structure; for in-depth investigation of advantages of PCM, latent storage was installed on the composite wall and on PV cells, and a reference façade structure was built (right, top); in-situ measurement data were used for post-validation of the CFD modeling and to determine overall energy performance indicators of the s- $\tau$ BIPV/T glazed façade structure.

The BIPV glazed façade structure installed was supplied [35] with 24 monocrystalline silicon PV cells $(156 \times 156 \mathrm{~mm})$ with reference efficiency of $18.5 \%$ encapsulated inside $4 \mathrm{~mm}$ hard glass layers on both sides. Encapsulated PCM latent storage produced by [36] was installed. Properties were taken from the literature [37], although the numerical modeling was validated with extensive experiments. Two W DC fans in size $40 \times 40 \mathrm{~mm}$ were installed, four in total.

\section{Design of semi-transparent building-integrated photovoltaic-thermal glazed façade structures (s- $\tau$ BIPV/T)}

The facade structure was designed taking into account simultaneous all predicted forms of solar energy utilization: electricity production, preheating of air for space ventilation, and combined operation of dynamic thermal insulation with solar-induced passive heating, which included the optimization of (a) packing factor of PV cells in glazed BIPV, (b) length of BIPV in the direction of air flow, (c) design of façade wall-integrated PCM storage and (d) design of PCM inserts built on the glass surfaces behind the PV cells.

The starting point of design was a definition of the air flow rate in the force-ventilated air gap. It was assumed that the s- $\tau$ BIPV/T will be installed on the façade of office buildings and be used for decentralized mechanical ventilation of an office. The constant outdoor air $\mathrm{CO}_{2}$ concentration of 500 ppm, the $\mathrm{CO}_{2}$ source of a single office occupant $800 \mathrm{mg}$ per minute (1.2 met, $1 \mathrm{clo}$ ) [38], duration of working time (8:00 to 17:00) with no breaks were assumed. Using a first-order concentration model for the prediction of transient $\mathrm{CO}_{2}$ concentration, it was found that maximum $\mathrm{CO}_{2}$ concentration in the office (which will be at the end of working time) will not exceed class III of indoor air quality (IAQ) [39] if the office is constantly ventilated with $19.5 \mathrm{~m}^{3}$ of fresh air per hour and that IAQ Class I will be established if the office is ventilated with $63 \mathrm{~m}^{3} / \mathrm{h}$ of the fresh air. Therefore, the $\mathrm{s}-\tau$ BIPV/T was 
designed, and experiments were performed at the set constant air flow rate $\dot{\mathrm{V}}_{\mathrm{a}, \mathrm{i}}$ in the ventilated air gap in the range between $15 \mathrm{~m}^{3} / \mathrm{h}$ and $65 \mathrm{~m}^{3} / \mathrm{h}$.

According to the proposed design of s- $\tau$ BIPV/T, the PV cell-packing factor not only impacts electricity production but also on the accumulated heat in PCM wall, which improves the efficiency of preheating of the air in the ventilated air gap.

Computational fluid dynamic (CFD) numerical simulations were used in the design process. The PHOENICS CFD tool was used, and transient numerical modeling was validated in several cases using in-situ measured data for selected days (the outdoor air temperature $T_{e}$ and solar irradiation $G_{g l o b, 90}$ on the surface of s- $\tau$ BIPV/T). The problem was treated as $2 \mathrm{D}$. Consequently, a checkboard arrangement of PV cells was replaced by a row arrangement, maintaining the same PV cell package factor. Based on previous research [40], it can be argued that such simplification does not affect the appropriate prediction of transient thermal response of the studied system. A turbulent flow pattern was predicted, and a ChenKim modified standard k- $\varepsilon$ dissipation approximation model was used, which improves the dynamic response of the epsilon equation by introducing an additional time scale [41]. Inner surface radiation heat transfer was modeled with the IMMERSOL module, while constant boundary combined surface heat transfer coefficient was assumed as $h_{c+r, i} 8 \mathrm{~W} / \mathrm{m}^{2} \mathrm{~K}$, and $\mathrm{h}_{\mathrm{c}+\mathrm{r}, \mathrm{e}} 15 \mathrm{~W} / \mathrm{m}^{2} \mathrm{~K}$. The average diurnal indoor air temperature $T_{i}$ for a particular day was determined via an in situ experiment and treated as a steady boundary condition. The optimization criteria were the average (of all) $\mathrm{PV}$ cell temperature $\mathrm{T}_{\mathrm{PV} \text {,avg, }}$, diurnal heat transferred by air $\mathrm{Q}_{\mathrm{a}, \mathrm{i}}$ and diurnal heat transferred at the inner surface of the s- $\tau$ BIPV/T $\mathrm{Q}_{\mathrm{i}}$. In Fig. 2, simulated values are shown. Simulations were performed using experimental data $\left(G_{\text {glob, } 90}, T_{e}\right.$ and $\mathrm{T}_{\mathrm{i}}$ ) gathered on at prototype structure (Fig. 1) on the 11 March 2020 as transient boundary conditions. The sunny day data was chosen for validation because, in such conditions, the impact of PV packing is the most evident. The delivered energy was summarized by using a compensation factor for electricity in the value of 2.5 as proposed by EPD support standard EN 52018-1 [42]. The diurnal delivered energy for the presented case study is $1589 \mathrm{Wh} /$ day for a packing factor of $30 \%, 1674 \mathrm{Wh} /$ day for a packing factor of $60 \%$, and $1528 \mathrm{Wh} /$ day for BIPV/T with a PV cell packing factor of $100 \%$. Comparing daily maximum average PV cell temperatures in s- $\tau$ BIPV/T with a $30 \%$ packing factor, it can be seen that average maximum modeled daily PV cell temperature is $7.5^{\circ} \mathrm{C}$ higher in the case of the $100 \%$ packing factor and $2.1{ }^{\circ} \mathrm{C}$ in case of the $60 \% \mathrm{PV}$ cell packing factor. Modeled PV cell temperatures were used in each time step for the determination of the efficiency of the PV cell, using the model presented in Section 5. 

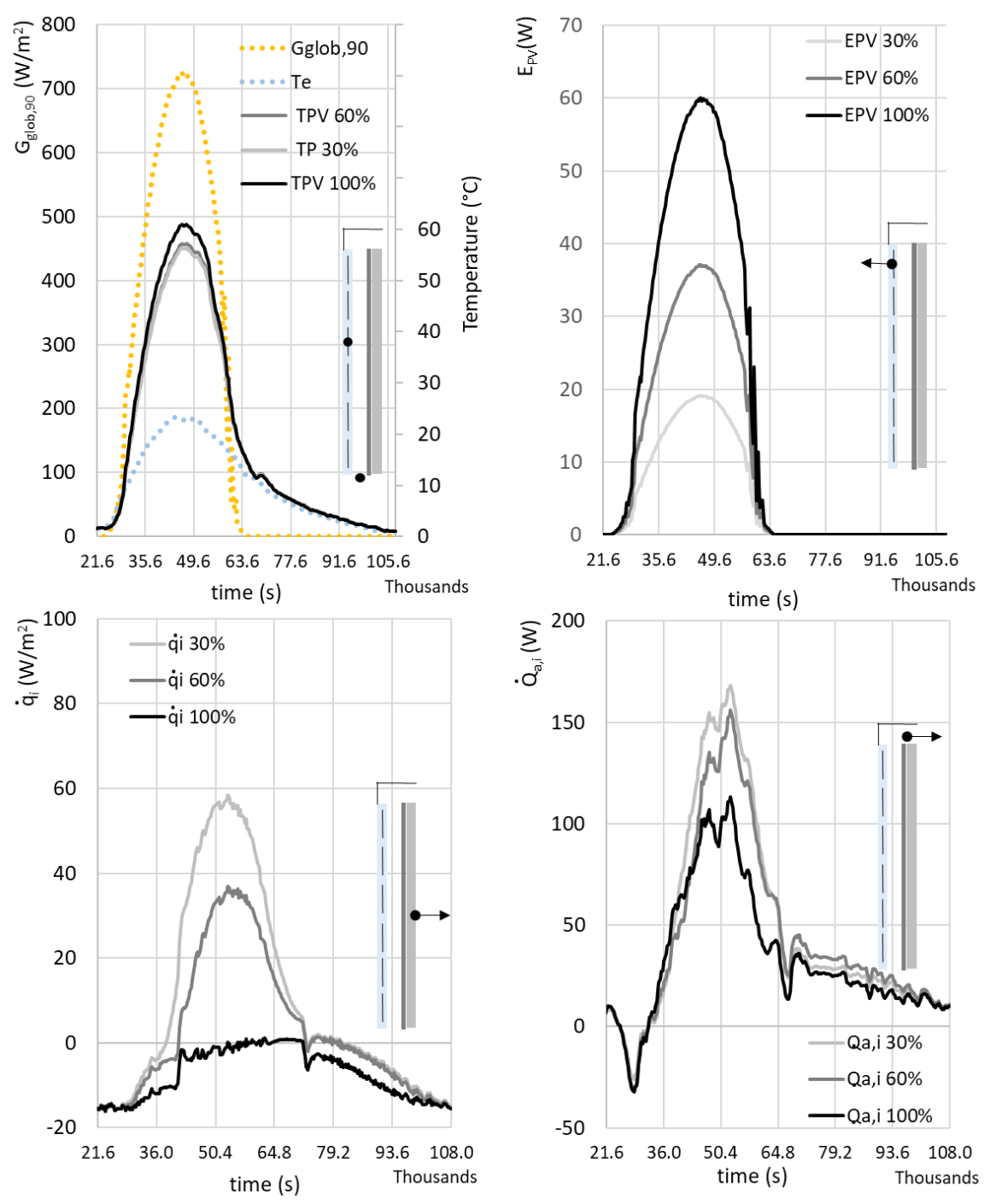

Fig. 2. The solar irradiation $\mathrm{G}_{\mathrm{glob}, 90}$, outdoor temperature $\mathrm{T}_{\mathrm{e}}$ and the average of $\mathrm{PV}$ cell temperatures (top, left), electricity power $E_{P V}$ (top, right), the specific heat flux $\dot{q}_{i}$ on the inner surface of the composite wall (bottom, left) and heat flux transferred by ventilation air $\dot{\mathrm{Q}}_{\mathrm{a}, \mathrm{i}}$ (bottom, right) in case of $30 \%, 60 \%$, and $100 \%$ PV cell packing in the prototype s- $\tau$ BIPV/T.

The impact of the length of s- $\tau$ BIPV/T on the energy performance of the structure was examined by modeling the transient temperature of the air in the ventilated gap along the $3 \mathrm{~m}$ tall s- $\tau$ BIPV/T. As in the previous cases, the CFD simulations were performed with measured data of 11 March 2020 (Fig. 2, top, left) as boundary conditions to emphasize the impact of influence parameters. In Fig. 3, the maximum diurnal air temperatures (at $46200 \mathrm{~s}$ ) in the case of BIPV with a 60\% PV packing factor are shown for two constant air inlet velocities (i.e., $0.2 \mathrm{~m} / \mathrm{s}$ and $0.5 \mathrm{~m} / \mathrm{s}$ ), which correspond to an air flow rate $23.5 \mathrm{~m}^{3} / \mathrm{h}$ and $58.7 \mathrm{~m}^{3} / \mathrm{h}$. Results are presented by the differences between average air temperature in the cross-section of the gap and the inlet (=outdoor) air temperature. The average temperatures in the cross-sections of the air gap were determined by the weighting of local (grid) temperatures with local (grid) velocities.

From Fig. 3 (top), it can be seen that in the case of a lower air flow rate assumed in numerical modeling, the temperature gradient showed nonlinearity above the $\sim 1.2 \mathrm{~m}$ height because heat losses increase due to the air temperature rise. Nevertheless, the temperature gradient increases through the entire length of the element, which leads to the conclusion that the optimal length of force ventilated s- $\tau$ BIPV/T cannot 
be determined, which is also evident in the case of the increased air flow rate. However, it can also be seen that air intended for ventilation of the building is preheated for $20^{+\circ} \mathrm{C}$ above outdoor air temperature at the height of s- $\tau \mathrm{BIPV} / \mathrm{T} \sim 1.2 \mathrm{~m}$, which can be indicated as a target value to eliminate ventilation heat losses, while protecting indoor space against overheating. In the case of larger air flow rate, the temperatures of preheated air are lower, but the linear temperature gradient indicates that the same approximation models of outlet air temperature could be used in the case of taller structures, by replacing the outdoor air temperature as air inlet temperature, by the approximated outlet air temperature of preheated air of the shorter (prototype) structure.

The average temperatures of PV cells were also studied. Fig. 3 (bottom) shows the average (surface) temperature of the encapsulated PV cells at the moment of maximum air temperature in the ventilated air gap for a selected day. Except for the PV cell in the bottom row, where the stream velocity profile is not yet formed, we can conclude that the temperature gradient of PV cell temperature is linear throughout the length of $3 \mathrm{~m}$ tall s- $\tau$ BIPV/T structure. This conclusion applies to both analyzed air flow rates. Accordingly, the approximation models of PV cell temperatures developed for the shorter element could be used in the case of taller façade structures by replacing outdoor air temperature as inlet air temperature with the modeled air temperature on the outlet of the air gap.

These findings led us to design prototype s- $\tau$ BIPV/T as a single PV module structure in the length of $1.2 \mathrm{~m}$ as a representative solution (Fig. 1).
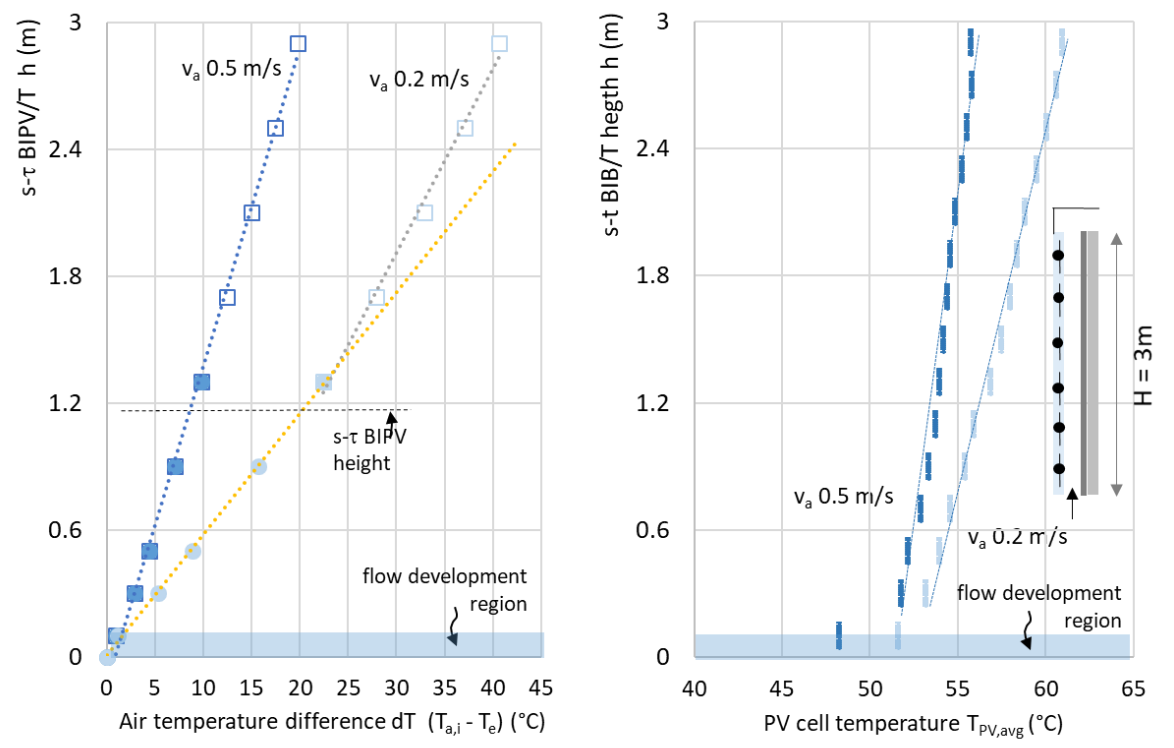

Fig. 3. Maximum diurnal difference in the temperature between the air temperature in the cross-section of the force-ventilated air gap and the outdoor air at height $h$ determined by numerical simulations using in-situ meteorological data for a clear sunny day (11 March 2020, Fig. 2) (top); the average temperature of PV cells along the BIPV in the moment of maximum air temperature in the air gap that occurs during the same day (bottom).

The prototype s- $\tau$ BIPV/T was designed to utilize solar energy with the highest efficiency during the heating season; nevertheless, the heat flux that transfers through the façade wall toward the building's interior should have at high diurnal average, while at low amplitude. In this way, both the risk of overheating of the indoor environment (during daytime) and heating load (during nighttime) is minimized. Because the prototype s- $\tau$ BIPV/T was designed to be built on a light-weight composite façade wall, those requirements can only be met if an additional layer of phase-change material is installed on the wall. Since the PCM storage also acts as a solar energy absorber in the prototype s- $\tau$ $\mathrm{BIPV/T}$, it was installed on the outer side of the composite façade wall and coated with high solar 
absorptance paint, as shown in Fig. 1. For the purposes of optimization, the PHOENICS CFD code was upgraded by using InForm command contend the discrete values of specific heat capacity $\mathrm{c}_{\mathrm{p}}$ depending on the temperature of the material, which read for each numerical cell and in each transient simulation step. Values from [37], shown in Fig. 4 (left), were assumed. Because latent heat storage is built with microencapsulated PCM structures, transient heat transfer in the PCM by conduction was assumed in numerical simulations. Simulations were performed using experimental data $\left(G_{g l o b, 90}\right.$ and $\left.T_{e}\right)$ gathered on 11 March 2020. The numerical solutions were validated by comparing surface temperatures on the top and the bottom side of PCM structure as well as by heat flux on the inner surface of the composite wall. According to the results shown in Fig. 4, it can be concluded that the assumed thermal properties of the encapsulated PCM structure, as well as the simulation model, were chosen correctly.
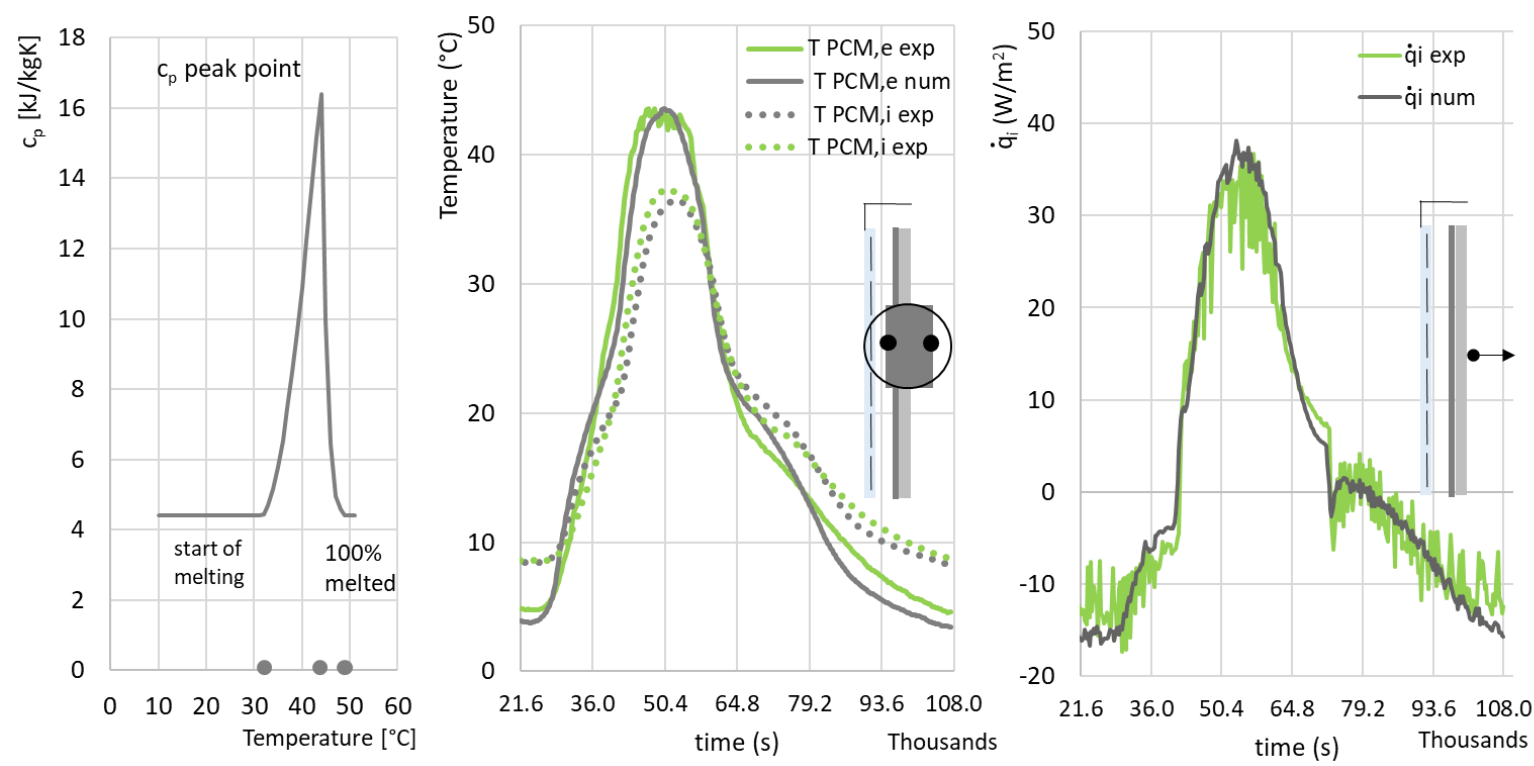

Fig. 4. Specific heat capacity of PCM inserted in InForm command of PHOENICS CFD code (left) [41], numerically determined and experimental temperatures on the outer in inner sides of the PCM layer (middle) and heat flux at the inner surface of the composite wall (right).

One of the most common reasons that PV modules are ventilated through backside air gaps is the cooling of the PV cells, which improves their efficiency. The effect of cooling can be further increased by decreasing the overheating of PV cells by storing the heat in the phase change material $[25,26]$, However, in the analyzed case, the BIPV in the form of a glazed façade, structures are built with relatively thick (4 to $5 \mathrm{~mm}$ ) double-sided hard glass layers, using material with a relatively low thermal conductivity $\left(\lambda_{\mathrm{g}} 0.76 \mathrm{~W} / \mathrm{mK}\right)$. In addition, the PCM material has even lower thermal conductivity at 0.2 $\mathrm{W} / \mathrm{mK}$. Consequently, the effect of PCM inserts on decreasing the temperature of PV cells must be proven, following findings presented in [13]. Depending on the setup and boundary conditions, the PCM inserts can act either as an efficient heat absorber (decreasing the PV cell temperature) or an insulation material (increasing the PV cell temperature). To justify the installation of PCM inserts, some PV cells were equipped with encapsulated PCM inserts, and the temperature on the surface of PCM inserts towards the ventilated air gap and on the plane glass behind the PV cells was measured simultaneously. At the same time, CFD modeling was used for the prediction of the temperature of encapsulated PV cells, both those with and without PCM inserts. The results of numerical modelling, which was previously validated, as shown in Fig. 4, and experimental results are presented in Fig. 5. It can be seen that during the daytime surface temperature of the PCM insert was significantly lower in comparison to the surface temperature of the glass, although the modelled temperature of PV cell shows almost no difference, which was also confirmed by IR imaging of the outer glass surface. This lead to the conclusion that PCM inserts will not provide any benefit regarding the increasing of the efficiency of 
PV cells; moreover, the lower surface temperature of PCM inserts will decrease the heat flux towards air in the ventilated gap. Because of that, the prototype s- $\tau$ BIPV/T was built without PCM inserts on the BIPV structure. In addition, numerical simulations were repeated for a set of measured meteorological data, and results were used for the forming of the parametric model of PV cell temperature.

The aim of the model is to determine the difference between the PV cell temperature and the surface glass temperature at the inner side of the BIPV glass pane, which was measured on different locations along the BIPV (indicated as $\mathrm{T}_{\mathrm{BIPV}, 4}$ and $\mathrm{T}_{\mathrm{BIPV}, 6}$ ). The model will be implemented in regression models for the determination of the hour-by-hour electricity production of BIPV. From statistical indicators, it was found that including the solar radiation $\mathrm{G}_{\mathrm{glob}, 90}$ as the only independent variable in the approximation model is sufficient, while the impact of other influence parameters (inlet air temperature $T_{e}$, air flow rate $\dot{\mathrm{V}}_{\mathrm{a}, \mathrm{i}}$ and wind speed $\mathrm{v}_{\mathrm{w}}$ ) is expressed by glass surface temperature.
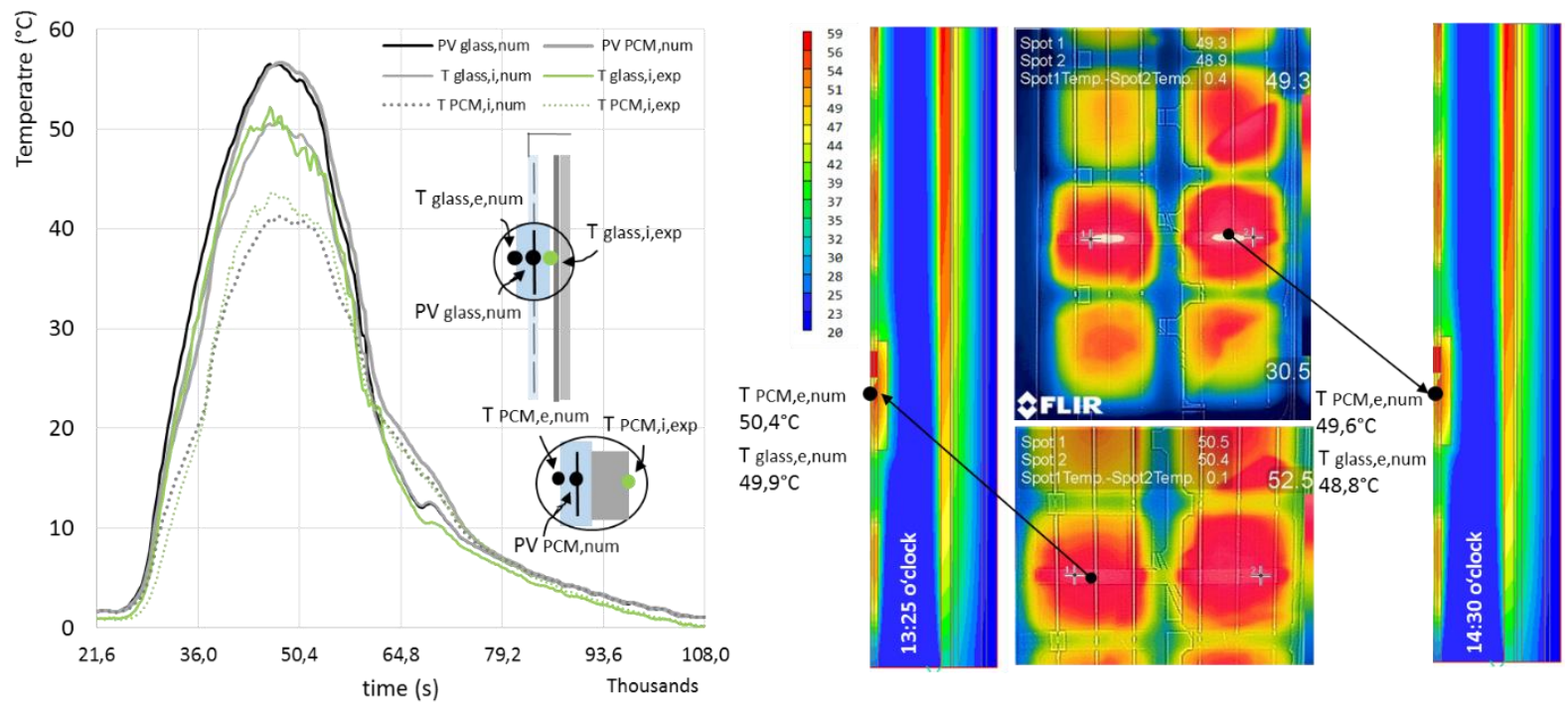

Fig. 5. In-situ determined PCM inserts and glass temperature on the surface towards the air gap and modeled PV cell temperatures (left), IR image of outer surface glass temperature compared with numerical simulations; a thin layer of translucent Lambertian emitter was taped on the glass above the second row of PV cells during IR imaging (right).

\section{Experimental setup and experimental data}

The prototype s- $\tau$ BIPV/T was built in the size of $3 \times 4 \times 3.5 \mathrm{~m}$, as shown in Fig. 1, and installed on a temperature-controlled building. The building was heated and occasionally cooled during solar noon periods by a split direct evaporation air conditioner. Although the appliance is equipped with a proportional-integral controller, the indoor temperature oscillates slightly, but even during sunny days, the indoor air temperature was kept in the range of the B quality class of indoor thermal comfort [39]. Calibrated and pre-paired K-type thermocouples were used for measuring the air temperature and surface temperatures of BIPV glass layers, PCM layers on the façade, and interior surface temperatures. At least two thermocouples were installed on each spot for measuring air temperature in the ventilated air gap.

The measured data were gathered in one-minute intervals. The following measured uncertainties were assumed: $\pm 0.5^{\circ} \mathrm{C}$ for thermocouples, $\pm 0.05 \mathrm{~m} / \mathrm{s}$ for hot wire velocity meter, $\pm 8 \%$ for heat flux meters, $\pm 5 \%$ for solar and IR irradiation measurements, $\pm 5 \%$ for wind speed and $\pm 0.5 \mathrm{~mm}$ for distance measurements. Meteorological parameters were measured in parallel with a Vantage Pro 2 weather station installed on the top of the test building. The experimental setup is presented in detail in [34]. 
In-situ experiments were performed from mid-December 2019 to mid-May 2020. The last period of the experiment (May) was monitored to gather a wider temperature range for modeling PV cell temperatures. The meteorological conditions during the experiments are shown in Fig. 6. During the experiments, the range of outdoor air temperature was from $-7.8^{\circ} \mathrm{C}$ to $25.2^{\circ} \mathrm{C}$ with an average value of $6.5^{\circ} \mathrm{C}$, wind speed between 0 and $8.6 \mathrm{~m} / \mathrm{s}$ with an average value of $0.6 \mathrm{~m} / \mathrm{s}$, and the range of diurnal solar radiation was between $390 \mathrm{Wh} / \mathrm{m}^{2}$ day to $5410 \mathrm{Wh} / \mathrm{m}^{2}$ day, with an average value of 2610 $\mathrm{Wh} / \mathrm{m}^{2}$ day.

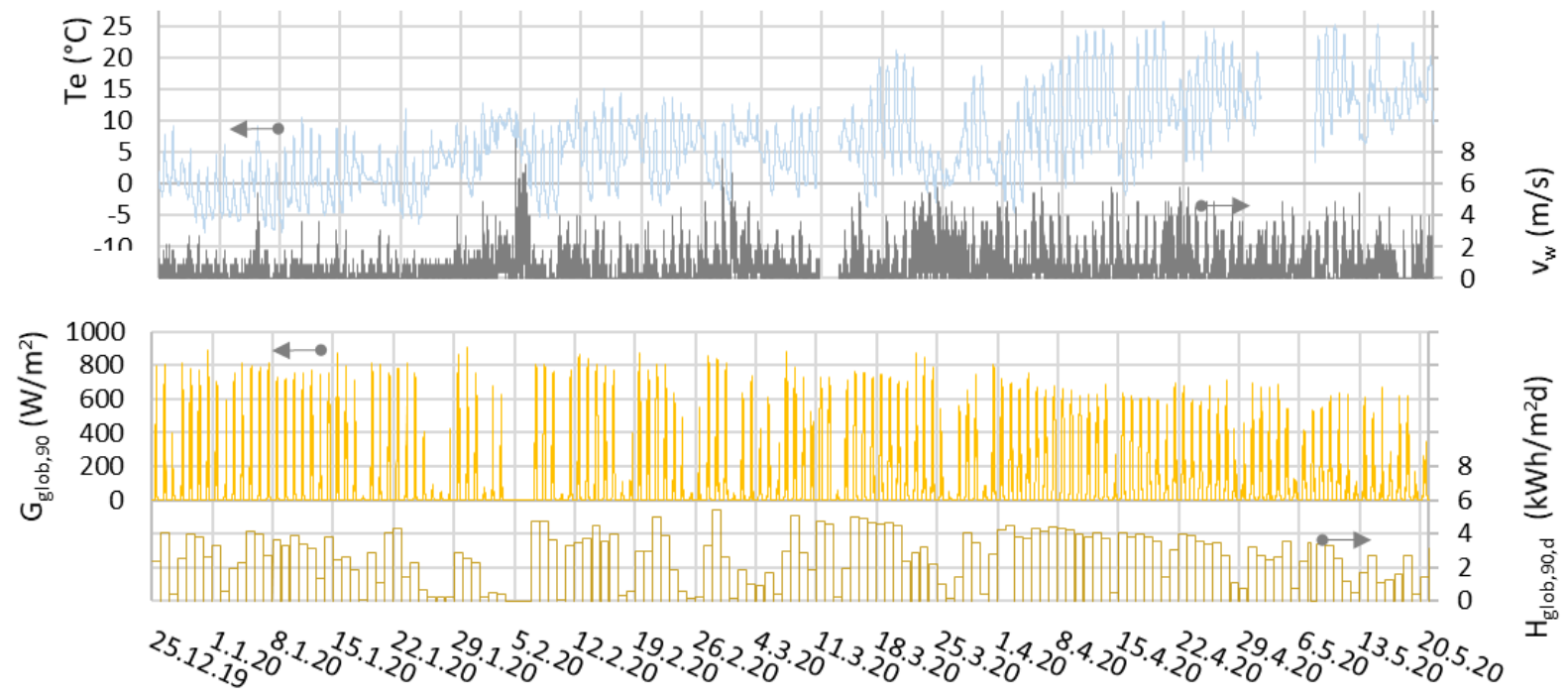

Fig. 6. Meteorological conditions during experiments, outdoor air temperature $T_{e}$, wind velocity $v_{W}$, solar irradiation $\mathrm{G}_{\mathrm{glob}, 90}$ and diurnal solar radiation $\mathrm{H}_{\mathrm{glob}, 90, \mathrm{~d}}$ on the surface of the s- $\tau$ BIPV/T.

\section{Energy efficiency metric of $s-\tau$ BIPV/T and multi-parametric regression models of energy efficiency indicators}

The energy efficiency metric of s- $\tau$ BIPV/T was developed to enable the comparison of the overall energy balance of the prototype with the energy balance of the thermally insulated façade in a naturally ventilated building during the heating season. Two groups of indicators are shown: in the first, the diurnal values are given; the second enables dynamic modeling on an hour-to-hour basis and is in the form of approximation models. The first set of indicators can be used in monthly evaluation methods taking into account the diurnal average values of meteorological and air flow-rate boundary conditions, while the second set enables the integration of s- $\tau$ BIPV/T in the dynamic modeling of a building's thermal response using computer tools, such as TRNSYS or IDA-ICE. Regardless of the type of the metrics, all indicators were developed on the basis of in-situ experimental data during the period shown in Section 4. The only exception is modeled electricity generation, for which the measured data on the optical properties of BIPV and the data on BIPV glass temperatures were used to design the parametric model of PV cell temperature. The procedure presented in [40] includes data on the reference efficiency of mcSi PV cells ( $\left.\eta_{\text {ref }} 18.5 \%\right)$ [35], temperature coefficient $\beta(-0.46 \% / \mathrm{K})[15,43]$ and PV cell efficiency correction factor at low levels of solar irradiation. The temperature correction factor $\mathrm{K}_{\mathrm{T}}$ includes an empirical model of PV cell temperature developed on the basis of the CFD modeling shown in Section 3:

$$
K_{T}=\eta_{r e f} \cdot\left(1+\beta \cdot\left((\overbrace{T_{B I P V, s i}+0.008076 \cdot G_{g l o b, \beta, 90}}^{T P V, c o r r})-25\right)\right)(-)
$$

Comparing the developed approximation model of PC cell temperature in BIPV with well-known Ross's model [44] shows that heat accumulation in the glass structure reduce the PV cell temperature by up to 
$5 \mathrm{~K}$ in the pre-solar noon period of clear sky day, that the peak temperature shifts for approximately one hour and that in dynamic (clear/cloudy sky) conditions, the differences occasionally exceed $20 \mathrm{~K}$.

While the heat flux on the inner surface of structure $\dot{q}_{i}$ and temperature of preheated air at the outlet of ventilated gap $T_{a, i}$ were measured, the total heat flux transported by preheated air $\dot{Q}_{a, i}$ was determined on the basis of a continuity equation, the calorimetric balance of the heat flux and measured values of air flow velocity, the air temperature on the inlet and outlet of the air gap, and the thermodynamic temperature-dependent air properties (i.e., specific heat capacity and density).

Some of the experimental results are shown in Fig. 7. Among experimental data, $6 \%$ of the diurnal values were excluded because at least one of the parameters was not stored correctly, and an additional 9 days were excluded from statistical observation for validation of the dynamic approximation models. These days were selected equally between clear sky, overcast sky, and extremely dynamic solar irradiation conditions.
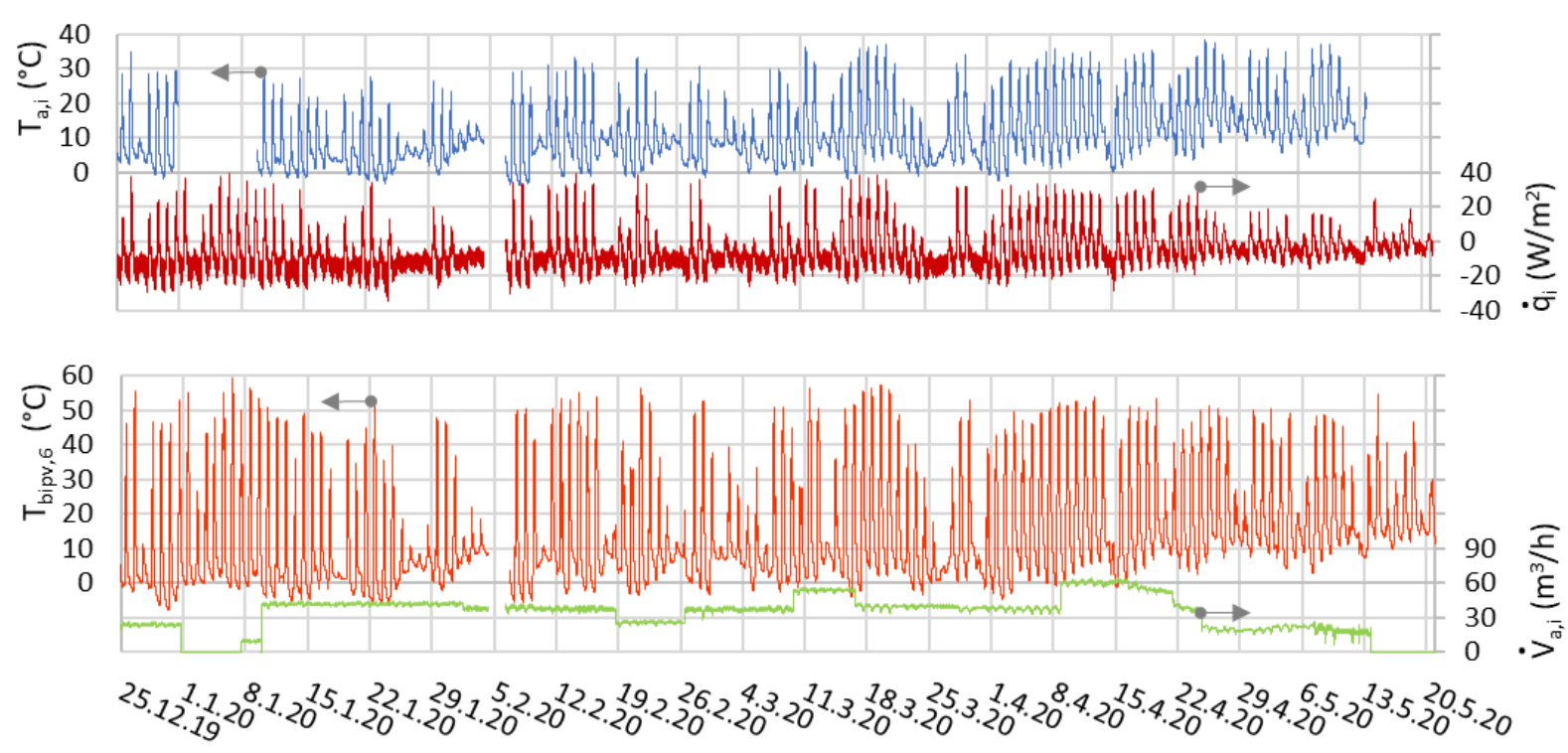

Fig. 7. Measured values of variables included in diurnal and dynamic approximation models of energy efficiency indicators; heat flux density at the inner surface of structure $\dot{\mathrm{q}}_{\mathrm{i}}$, temperature of preheated supply air $T_{a, i}, B I P V$ glass temperature on the $6^{\text {th }}$ row of PV cells $T_{B I P V, 6}$, ventilation air flow rate $\dot{V}_{a, i}$

\subsection{Diurnal energy efficiency indicators}

The diurnal indicators were constructed to emphasize the most obvious advantages of the developed façade structure during the heating season. The dynamic thermal insulation mode that results from air gap ventilation and the simultaneous utilization of solar energy is evaluated by dynamic thermal transmittance $U_{\text {eff }}$, preheating of the air mode by air preheating efficiency $\varepsilon_{\mathrm{v}}$ of ventilation air and latent heat storage with the diurnal amplitude of heat flux at the inner surface of the composite wall $\hat{\dot{q}}_{i}$. Diurnal indicators are defined in the following way: $\mathrm{U}_{\text {eff }}$ as average instantaneous thermal transmittance measured between 6:00 in the morning to 6:00 in the next morning to neglect the impact of the heat of solar radiation stored in elements of s- $\tau \mathrm{BIPV} / \mathrm{T}, \varepsilon_{\mathrm{v}}$ by a temperature increase of ventilation air, which enters the structure from outdoor during occupied hours in the office building and $\hat{\dot{q}}_{i}$ by averaging the 5 highest values of heat flux at the indoor structure surface $\dot{\mathrm{q}}_{\mathrm{i}}$ to compensate dynamic in-situ boundary conditions. The office-type building was studied because of the high potential of BIPV utilization in 
such buildings. The following equations were used, taking into account the discrete set of data gathered in one-minute intervals:

$$
\begin{gathered}
\mathrm{U}_{\mathrm{eff}}=\frac{1}{\Delta \mathrm{t}} \int_{6: 00}^{6: 00+} \frac{\dot{\mathrm{q}}_{\mathrm{i}}}{\left(\mathrm{T}_{\mathrm{i}}-\mathrm{T}_{\mathrm{e}}\right)} \cdot \mathrm{dt} \rightarrow \frac{1}{1440} \sum_{\mathrm{j}=1}^{1440} \frac{\dot{\mathrm{q}}_{\mathrm{i}, \mathrm{j}}}{\left(\mathrm{T}_{\mathrm{i}, \mathrm{j}}-\mathrm{T}_{\mathrm{e}, \mathrm{j}}\right)} \\
\varepsilon_{\mathrm{v}}=\frac{1}{\Delta \mathrm{t}} \int_{9 \mathrm{~h}}^{17: 00} \frac{\left(\mathrm{T}_{\mathrm{a}, \mathrm{i}}-\mathrm{T}_{\mathrm{e}}\right)}{\left(\mathrm{T}_{\mathrm{i}}-\mathrm{T}_{\mathrm{e}}\right)} \cdot \mathrm{dt} \rightarrow \frac{1}{540} \sum_{\mathrm{j}=1}^{540} \frac{\left(\mathrm{T}_{\mathrm{a}, \mathrm{i}, \mathrm{j}}-\mathrm{T}_{\mathrm{e}, \mathrm{j}}\right)}{\left(\mathrm{T}_{\mathrm{i}, \mathrm{j}}-\mathrm{T}_{\mathrm{e}, \mathrm{j}}\right)} \\
\hat{\dot{\mathrm{q}}}_{\mathrm{i}}=(\mathrm{nl} \arg \operatorname{est}\left(5, \dot{\mathrm{q}}_{\mathrm{i}}\right)-\frac{1}{\Delta \mathrm{t}} \int_{6: 00}^{6: 00+} \dot{\mathrm{q}}_{\mathrm{i}} \cdot \mathrm{dt} \rightarrow \underbrace{\left(\mathrm{nl} \arg \text { est }\left(5, \dot{\mathrm{q}}_{\mathrm{i}}\right)\right.}_{\text {average of } 5 \text { largest } \dot{\mathrm{q}}_{\mathrm{i}}}-\underbrace{\frac{1}{1440} \sum_{\mathrm{j}=1}^{1440} \dot{\mathrm{q}}_{\mathrm{i}, \mathrm{j}}}_{\text {diurnal average } \dot{\mathrm{q}}_{\mathrm{i}}}
\end{gathered}
$$

To show the advantage of latent heat storage, $U_{\text {eff }}$ and $\hat{\dot{q}}_{i}$ were also determined for the reference $s-\tau$ BIPV/T (Fig. 1), which was ventilated with the same air flow rate. The results of the evaluation are shown in Fig. 8. In addition to the indicators mentioned above, the static thermal transmittance $U$ was determined using experimental data from the period between 2:00 and 6:00 in the morning, which is a period of steady heat transfer. The theoretical value of $U$ for the composite wall is $1.027 \mathrm{~W} / \mathrm{m}^{2} \mathrm{~K}$ and for composite wall with PCM layers $0.96 \mathrm{~W} / \mathrm{m}^{2} \mathrm{~K}$.

From Fig. 8 (top), it can be seen that the dynamic thermal transmittance ("a") at low diurnal solar radiation evaluated for the reference wall is very close to the static value, while $\mathrm{U}_{\text {eff }}$ is appx. $15 \%$ bellow $\mathrm{U}$ in the case of the composite wall with PCM. The reason for was determined to be the additional resistance to heat transfer between the layers caused by micro air gaps and the low emissivity surface of PCM layers, which indicates that contact resistance to heat transfer must be taken into account with caution in the process of numerical modeling. The impact of storing solar energy is evident from the significantly higher slope of $\mathrm{U}_{\text {eff }}$ decreasing at higher diurnal solar radiation in the case of the composite wall with PCM ("b"). While $\mathrm{U}_{\text {eff }}$ decreases to $0.4 \mathrm{~W} / \mathrm{m}^{2} \mathrm{~K}$ at diurnal solar radiation above $2200 \mathrm{Wh} / \mathrm{m}^{2}$ in case of the wall with PCM storage, this will be achieved in the case of the composite wall without PCM storage at diurnal solar radiation above $5000 \mathrm{Wh} / \mathrm{m}^{2}$. The outdoor temperature has a minor impact on $\mathrm{U}_{\text {eff }}$ ("c") up to average diurnal temperature below $15^{\circ} \mathrm{C}$, while at higher temperatures $\mathrm{U}_{\text {eff }}$ drops, because of the interaction between solar irradiation and outdoor air temperature. No significant impact of wind speed on $\mathrm{U}_{\text {eff }}$ could be seen. The $\mathrm{U}_{\text {eff }}$ of the composite wall with PCM decreases with a gradient $\left(\Delta \mathrm{U}_{\text {eff }} / \Delta \mathrm{H}_{\mathrm{glob}, 90}\right)$ of 0.4 (Wday/KkWh) in the case of a non-ventilated air gap, by 0.16 (Wday/KkWh) in the case of air flow rates $\dot{\mathrm{V}}_{\mathrm{a}, \mathrm{i}}$ between 10 to $15 \mathrm{~m}^{3} / \mathrm{h}$, by 0.12 (Wday/KkWh) in case of $\dot{\mathrm{V}}_{\mathrm{a}, \mathrm{i}}$ in the range between 20 to $45 \mathrm{~m}^{3} / \mathrm{h}$ and by 0.10 (Wday/KkWh) for $\dot{\mathrm{V}}_{\mathrm{a}, \mathrm{i}}$ up to $60 \mathrm{~m}^{3} / \mathrm{h}$.

Average preheating air efficiency $\varepsilon_{\mathrm{v}, \text { avg }}$ is shown in Fig. 8. (middle). It should be pointed out that $\varepsilon_{\mathrm{v}, \text { avg }}$ was evaluated during the ventilation operation period (8:00 to 17:00 daily). At low diurnal solar radiation $\left(\mathrm{H}_{\text {glob,90 }}<500 \mathrm{Wh} / \mathrm{m}^{2}\right.$ day), the $\varepsilon_{\text {v.avg }}$ was around $10 \%$ ("a"), which results from dynamic thermal insulation heat transfer, with low impact of outdoor air temperature $\mathrm{T}_{\mathrm{e}, \mathrm{avg}, \mathrm{occ}}$ during building-occupied hours. At low ventilation air flow rates $\dot{\mathrm{V}}_{\mathrm{a}, \mathrm{i}}$, the $\varepsilon_{\mathrm{v} \text {.avg }}$ above $100 \%$ occurs at diurnal solar radiation above $2200 \mathrm{Wh} / \mathrm{m}^{2}$ day, while at mid-range of $\dot{\mathrm{V}}_{\mathrm{a}, \mathrm{i}}, \varepsilon_{\mathrm{v} . \text { avg }}$ increases almost proportionally with outdoor air temperature and solar radiation ("b") and reach $50 \%$ at outdoor air temperatures $\mathrm{T}_{\mathrm{e}, \text { avg,occ }}$ above $7.0^{\circ} \mathrm{C}$ and at diurnal solar radiation above $2200 \mathrm{Wh} / \mathrm{m}^{2}$ day. The $\varepsilon_{\mathrm{v}, \text { avg }}$ above $100 \%$ was observed at $\mathrm{T}_{\mathrm{e}, \text { avg,occ }}$ above $15^{\circ} \mathrm{C}$ ("c"); nevertheless, ventilation losses, in this case, are irrelevant due internal heat gains and these cases are not shown in Fig. 8 (middle). The impact of ventilation air flow rate $\dot{\mathrm{V}}_{\mathrm{a}, \mathrm{i}}$ as well as wind speed $\mathrm{v}_{\mathrm{w}}$ were observable but can only be evaluated using short-time (hourly) step approximation 
models. When designing the prototype s- $\tau \mathrm{BIPV} / \mathrm{T}$, one of the goals was to decrease the diurnal amplitude of heat flux $\hat{\dot{q}}_{i}$ on the indoor surface of the façade structure.

To emphasize the impact of heat storage in PCM layers installed on the composite wall, Fig. 8 (bottom) shows the $\hat{\dot{q}}_{\mathrm{i}}$ for the reference wall as well. At low diurnal solar radiation $\left(\mathrm{H}_{\mathrm{glob}, 90, \mathrm{~d}}<500 \mathrm{Wh} / \mathrm{m}^{2}\right.$ day $)$, $\hat{\dot{\mathrm{q}}}_{\mathrm{i}}$ was $\sim 5 \mathrm{~W} / \mathrm{m}^{2}$ for both structures, due to the outdoor air temperature variation, and partially also because of the indoor air temperature variation. With the increasing of the diurnal solar radiation, the impact of PCM becomes obvious and at high diurnal solar radiation $\left(\mathrm{H}_{\mathrm{glob}, 90, \mathrm{~d}}>4000 \mathrm{Wh} / \mathrm{m}^{2}\right.$ day $)$, the $\hat{\mathrm{q}}_{\mathrm{i}}$ of the wall with PCM layer ("a") is almost only half of that of the reference structure $\left(40 \mathrm{~W} / \mathrm{m}^{2}-23\right.$ $\mathrm{W} / \mathrm{m}^{2}$ ), with a low impact of outdoor air temperature. In the mid-range of diurnal solar radiation values, $\hat{\dot{\mathrm{q}}}_{\mathrm{i}}$ increases at a rate of $2.5 \mathrm{Wday} / \mathrm{kWh}$ in the case of the structure with PCM layer and $\sim 5.5 \mathrm{Wday} / \mathrm{kWh}$ in the case of the reference structure. In both cases, the average diurnal heat flux $\dot{q}_{i}$ is proportional to the dynamic thermal transmittance $U_{\text {eff }}$ of the structures.

Although the diurnal indicators correctly show the energy performance of the prototype s- $\tau$ BIPV/T, and the statistical evaluation of the approximation models confirm that diurnal indicators can be modeled by multi-parametric models and used in the monthly building energy balance simulation method (for example), the dynamic thermal response of s- $\tau$ BIPV/T could only be predicted by the hourly time-step dynamic regression models. In this way, the performance modeling of the prototype s- $\tau$ BIPV/T can be included in available dynamic simulation computer codes (e.g., TRNSYS, EnergyPlus or IDA-ICE). 

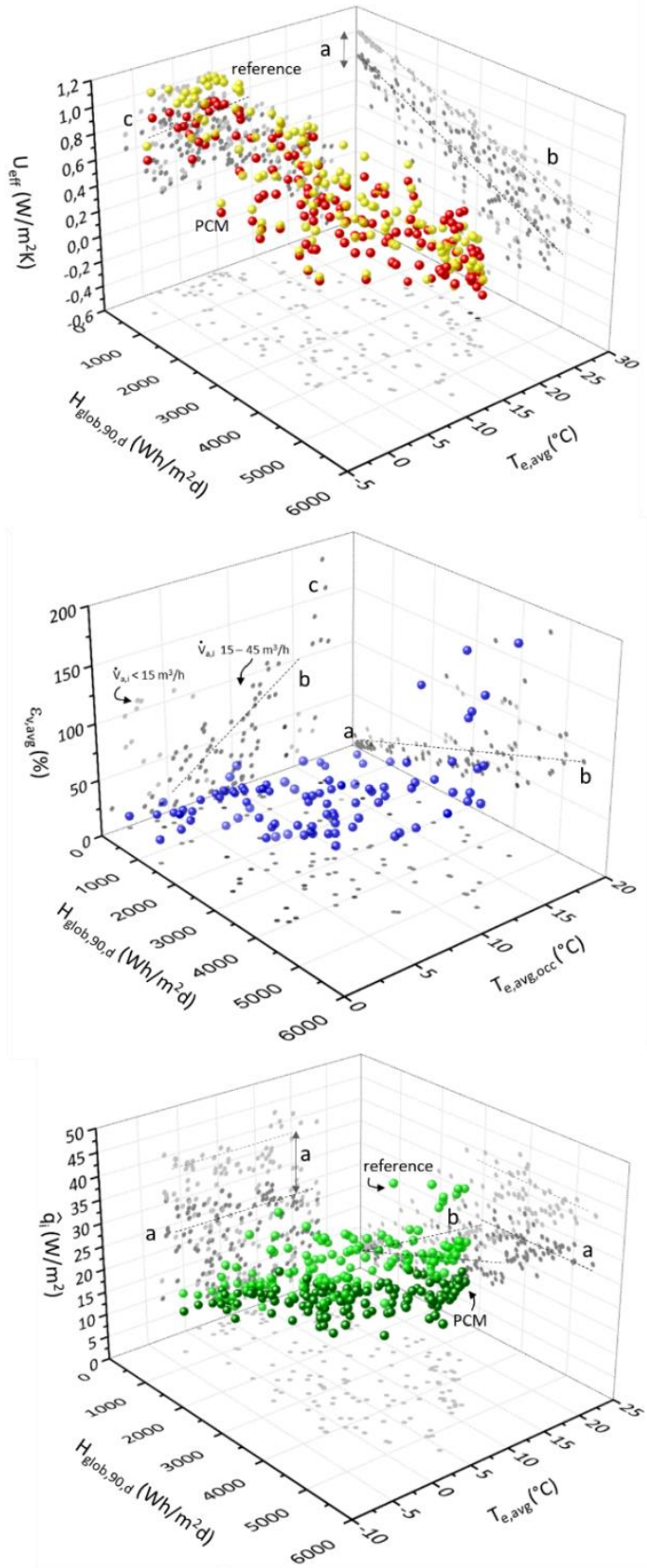

Fig. 8. Diurnal energy efficiency indicators of the prototype s- $\tau$ BIPV/T; dynamic thermal transmittance $\mathrm{U}_{\text {eff }}$ (top), the average efficiency of preheating of the ventilation air $\varepsilon_{\mathrm{v}, \text { avg }}$ during office working hours (middle), the diurnal amplitude of heat flux at the inner surface of the structure $\hat{\dot{q}}_{\mathrm{i}}$ (bottom) determined from in-situ measurements.

\subsection{Dynamic regression models of energy efficiency indicators}

From the analysis of in-situ data and from the observation of values of diurnal indicators, it can be seen that diurnal indicators are highly dependent on the dynamic condition and the range of boundary data that appears during in-situ experiments. Although the diurnal models of energy efficiency indicators can be used in simplified monthly methods of building energy performance evolution, they are not adequate for hour-to-hour modeling of building thermal response. Because of that, a step-by-step evolution of the most appropriate types of dynamic approximation model was done. The following models were examined: multiple linear regression model (MLR) (eq. 5); multiple regression model with interactions 
(MRX) (eq. 6), because in in-situ experiments independent meteorological variables are always mutually dependent; and multiple regression model with interactions and past values (MRXP) (eq. 7), because some of the energy efficiency indicators respond with a time shift to boundary meteorological conditions.

$$
\begin{gathered}
y=a_{0}+\sum_{i=1}^{n}\left(a_{i} \cdot x_{i}\right) \\
y=a_{0}+\sum_{i=1}^{n}\left(a_{i} \cdot x_{i}\right)+\sum_{j=1}^{m}\left(b_{j} \cdot x_{a} \cdot x_{b}\right)+\sum_{k=1}^{1}\left(c_{k} \cdot \frac{x_{a}}{x_{b}}\right) \quad x_{a}, x_{b} \in\left(x_{1} \ldots x_{n}\right) \\
y=a_{0}+\sum_{i=1}^{n} \sum_{j=0}^{6}\left(a_{i, j} \cdot x_{i}^{t-j}\right)+\sum_{l=1}^{m}\left(b_{1} \cdot x_{a} \cdot x_{b}\right)+\sum_{k=1}^{h}\left(c_{k} \cdot \frac{x_{a}}{x_{b}}\right) \quad x_{a}, x_{b} \in\left(x_{1} \ldots x_{n}\right)
\end{gathered}
$$

where $x$ is independent variables, and $t$ is the present time step. Regression models were developed for the prototype s- $\tau$ BIPV/T using following energy efficiency indicators: instantaneous power of electricity generator $E_{P V}$ (in $W$ ), supply ventilation air temperature $T_{a, i}$, heat flux transmitted by ventilation air to the building $\dot{\mathrm{Q}}_{\mathrm{a}, \mathrm{i}}$ (in W) and the density of heat flux on the inner surface of the façade wall $\dot{q}_{i}\left(\right.$ in $\left.\mathrm{W} / \mathrm{m}^{2}\right)$. These models are needed for the holistic evaluation of the s- $\tau$ BIPV/T façade structure.

In the process of the development of regression models, hourly average experimental data were used, leading to the development of hourly time-step models. The hourly time step is most commonly used in the modeling of thermal response of the buildings. The discrete hourly values were determined as average values at full hours considering previous and next half hour time interval.

Regression coefficients and statistical criteria were obtained with an automated procedure integrated as an MS Excel macro. The code can evaluate the impact of the following independent variables: solar irradiation $\mathrm{G}_{\mathrm{glob}, 90}$, outdoor $\mathrm{T}_{\mathrm{e}}$ and indoor $\mathrm{T}_{\mathrm{i}}$ air temperatures, wind velocity $\mathrm{v}_{\mathrm{w}}$, and ventilation air flow rate $\dot{\mathrm{V}}_{\mathrm{a}, \mathrm{i}}$; each of them can be evaluated in six past-time levels. The following interactions were also

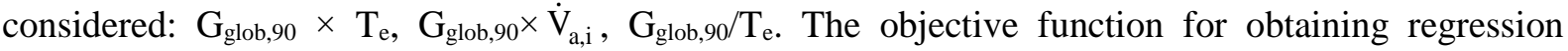
coefficients of dynamic approximation models (eqs. 5-7) is the least square method, with the goal of minimizing the sum of the least square errors between measured and predicted energy efficiency indicators. It was done with the built-in LINEST function. Automated procedure considers stepwise regression method with backward elimination technique for influential independent variables. The significance of independent variables was tested using T.DIST.2T function. The developed macro excludes variables with a p-value greater than 0.05 .

The accuracy of the developed regression models was tested with several statistical indicators, including those recommended by ASHRAE [45]: the Coefficient of Determination $\left(\mathrm{R}^{2}\right)$, the Root Mean Square Error (RMSE), the Normalized Mean Bias Error (NMBE), and the Coefficient of Variation of Root Mean Square Error (CV(RMSE)).

$$
R^{2}=\left(\frac{n \cdot \sum_{i=1}^{n} M_{i} \cdot P_{i}-\sum_{i=1}^{n} M_{i} \cdot \sum_{i=1}^{n} P_{i}}{\sqrt{\left(n \cdot \sum_{i=1}^{n} M_{i}^{2}-\left(\sum_{i=1}^{n} M_{i}\right)^{2}\right) \cdot\left(n \cdot \sum_{i=1}^{n} P_{i}^{2}-\left(\sum_{i=1}^{n} P_{i}\right)^{2}\right)}}\right)^{2}
$$


$R^{2}$ indicates how close predicted energy efficient indicator values $P_{i}$ are to the measured $\left(T_{a, i}, \dot{q}_{i}\right)$ or calculated ( $\left.E_{P V}, \dot{Q}_{a, i}\right)$ values $\mathrm{M}_{\mathrm{i}}$. Hourly values of $\mathrm{M}_{\mathrm{i}}$ at time $\mathrm{t}$ were determined from measured values ( 1 min intervals) averaged in the interval $t-30 \mathrm{~min}$ to $\mathrm{t}+30 \mathrm{~min}$. The number of observations $\mathrm{n}$ was 24 hours per day for 127 days out of 145 days in case of $\dot{\mathrm{q}}_{\mathrm{i}}$. For $\mathrm{E}_{\mathrm{PV}}$ only when $\mathrm{G}_{\mathrm{glob}, 90}$ was above $0 \mathrm{~W} / \mathrm{m}^{2}$. For the energy efficiency indicators $\left(\mathrm{T}_{a, i}, \dot{\mathrm{Q}}_{\mathrm{a}, \mathrm{i}}\right)$ related to preheating of ventilation air, 110 days was considered in which the air flow rate in the force-ventilated air gap was greater than $0 \mathrm{~m}^{3} / \mathrm{h}$.

$$
\text { RMSE }=\sqrt{\left(\frac{1}{n} \cdot \sum_{i=1}^{n}\left(P_{i}-M_{i}\right)^{2}\right)}
$$

The RMSE represents the standard deviation of the prediction errors. The RMSE of the approximation model is more responsive to the more deviating values due to quadratic dependence of the error.

$$
\text { NMBE }=\frac{n}{\sum_{i=1}^{n} M_{i}} \cdot \frac{\sum_{i=1}^{n}\left(M_{i}-P_{i}\right)}{n-p} \cdot 100
$$

The NMBE is a normalization of the Mean Bias Error. It provides the global difference between the measured (calculated) values and the predicted ones. Positive value means that the model gives underestimated values.

$$
\mathrm{CV}(\mathrm{RMSE})=\frac{\mathrm{n}}{\sum_{\mathrm{i}=1}^{\mathrm{n}} \mathrm{M}_{\mathrm{i}}} \cdot \sqrt{\frac{\sum_{\mathrm{i}=1}^{\mathrm{n}}\left(\mathrm{M}_{\mathrm{i}}-\mathrm{P}_{\mathrm{i}}\right)^{2}}{\mathrm{n}-\mathrm{p}}} \cdot 100
$$

The CV(RMSE) indicates the variability of errors between measured (calculated) values and the predicted ones. It is recognized as one of the most important indicator of forecast ability of the approximation model [46]. The following values of statistical indicators are requested for hourly regression models: $\mathrm{R}^{2}>75 \%, \mathrm{NMBE}< \pm 10 \%$ and $\mathrm{CV}(\mathrm{RMSE})<30 \%$. Details are presented in $[47,48]$.

Though we intended to develop the regression model in the simplest possible form (MLR or MLX), it was found that such models are not adequate even in the case of indistinct dynamic changes in boundary conditions (e.g., clear sky or overcast sky). The only exception is the prediction of electricity production in which the MRXP model shows only minor advantages over models that are not content time history information (Fig. 9). The simplest model can adequately predict the heat flux density at the inner surface of the structure (Fig. 10) only in case of low daily solar radiation (Fig. 10, middle). At higher daily solar radiation, the difference in amplitude and time shift of heat flux increases, which is evident in the case of the almost clear sky conditions presented in Fig. 10, left. The variation of indoor air temperature caused by the transition from heating to cooling during midday is one potential reason for the discrepancies between measured and predicted values. Among all the analyzed indicators, the heat flux transferred by preheated air for ventilation $\dot{Q}_{a, i}$ is the most dynamic because of the high impact of the wind velocity. Nevertheless, the MRXP model is the most suitable prediction model according to the dynamics and absolute values of $\mathrm{q}_{\mathrm{a}}$ (Fig. 11). From Fig. 12, it can be seen that the difference between the models in prediction of the supply ventilation air temperature $T_{a, i}$ differ less in comparison to the prediction models for $\dot{\mathrm{q}}_{\mathrm{i}}$ and $\dot{\mathrm{Q}}_{\mathrm{a}, \mathrm{i}}$; nevertheless, the difference in the amplitude of temperature increases with increased solar irradiation. This was also confirmed by comparing statistical indicators that show that only MRXP fulfills all the criteria required by [45]. 
Following these observations as well as statistical indicators, it is evident that only MRXP models are adequate for modeling the energy efficiency of the presented prototype of s- $\tau$ BIPV/T. The selected impact variables and regression coefficients for these regression models are shown in Table 1 . The statistical metric is also shown. It can be concluded that the proposed regression models are adequate. The only criterion that slightly exceeded the target value is the CV(RMSE) of the $\dot{q}_{i}$. To confirm the adequacy of the model on the diurnal time scale, the daily integral values determined by integrating the experimental and the modeled values were compared. The analysis showed that the hourly regression model predicts the diurnal heat transfer through the façade wall with adequate accuracy; the CV(RMSE) is $11.7 \%$, which means that the diurnal balance of $\dot{\mathrm{q}}_{i}$ can be considered adequate even in dynamic boundary conditions with some discrepancies in the dynamic thermal response.
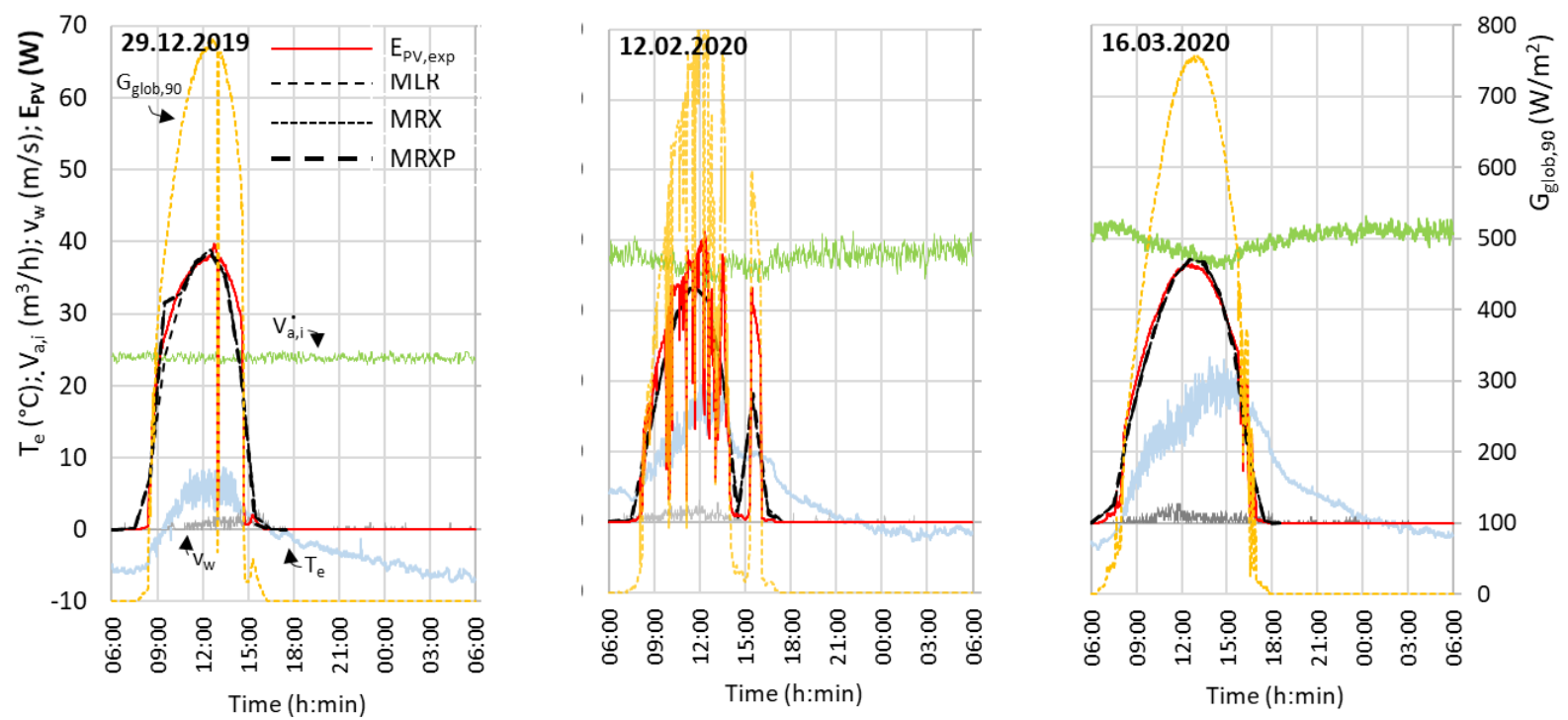

Fig. 9. Experimental data and prediction of electrical power $E_{P V}$ of BIPV with the MLR, MRX, and MRXP models for three selected days
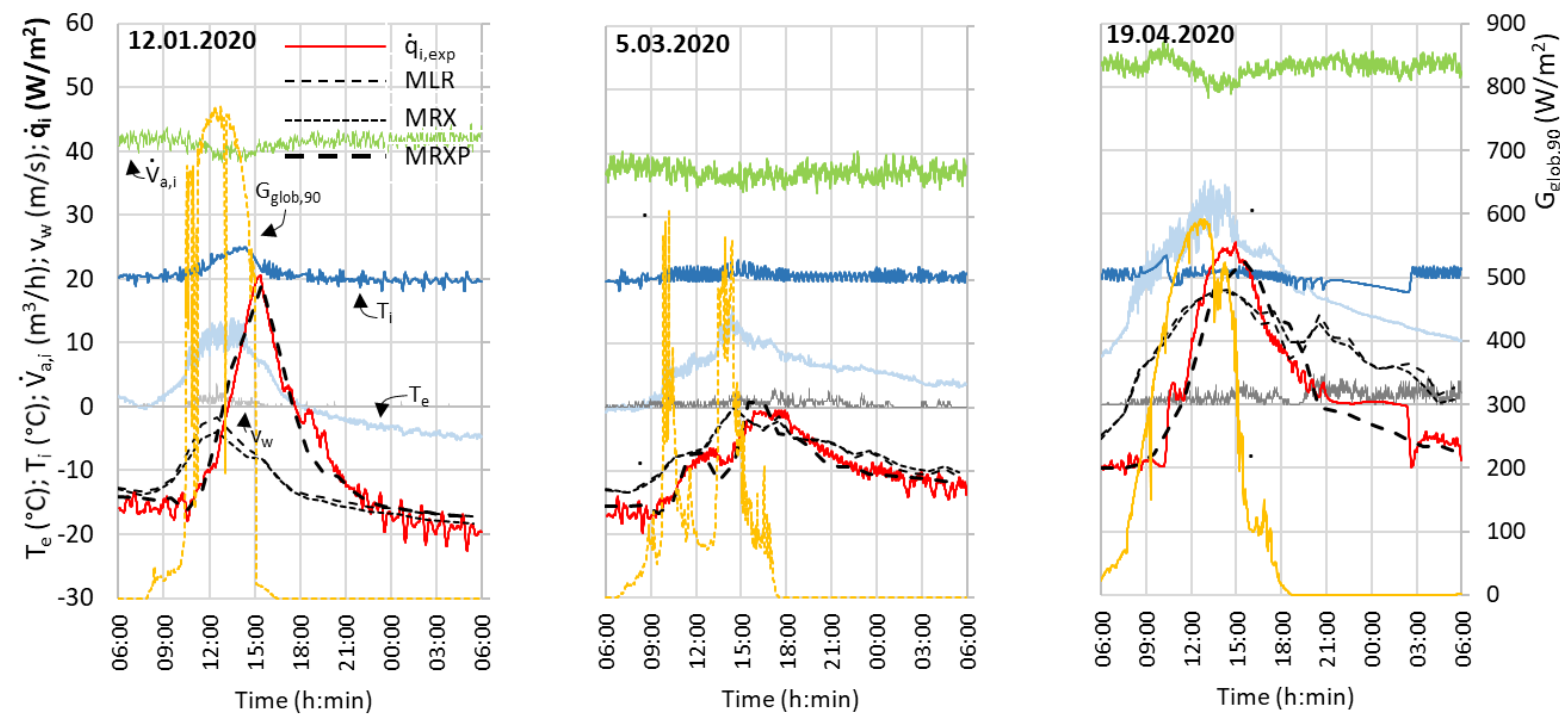

Fig. 10. Experimental data and prediction of the density of heat flux $\dot{\mathrm{q}}_{\mathrm{i}}$ at the inner surface of the s- $\tau$ BIPV/T with MLR, MRX, and MRXP models for three selected days 

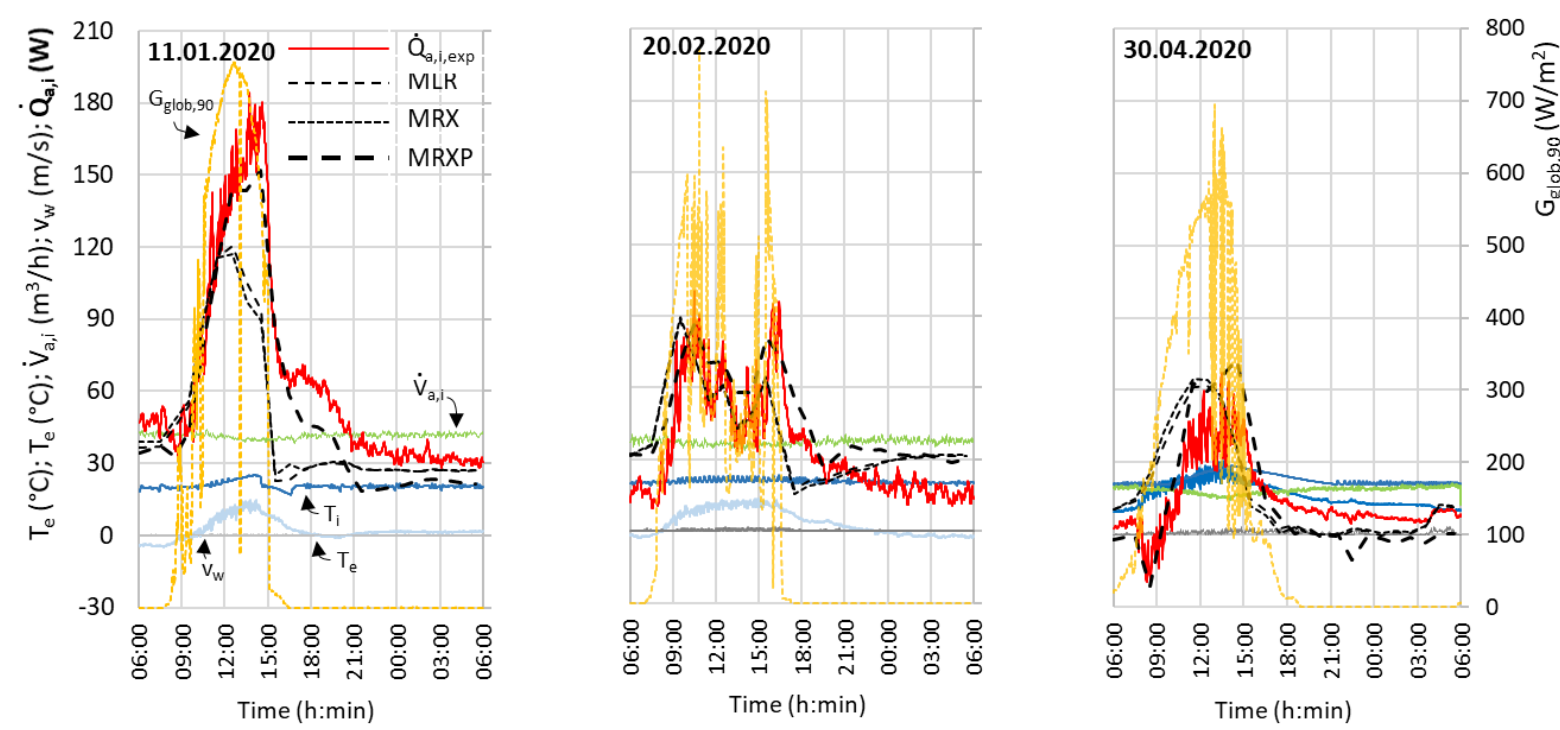

Fig. 11. Experimental data and prediction of the total heat flux transferred by ventilation air $\dot{Q}_{a, i}$ modeled with the MLR, MRX, and MRXP models for three selected days
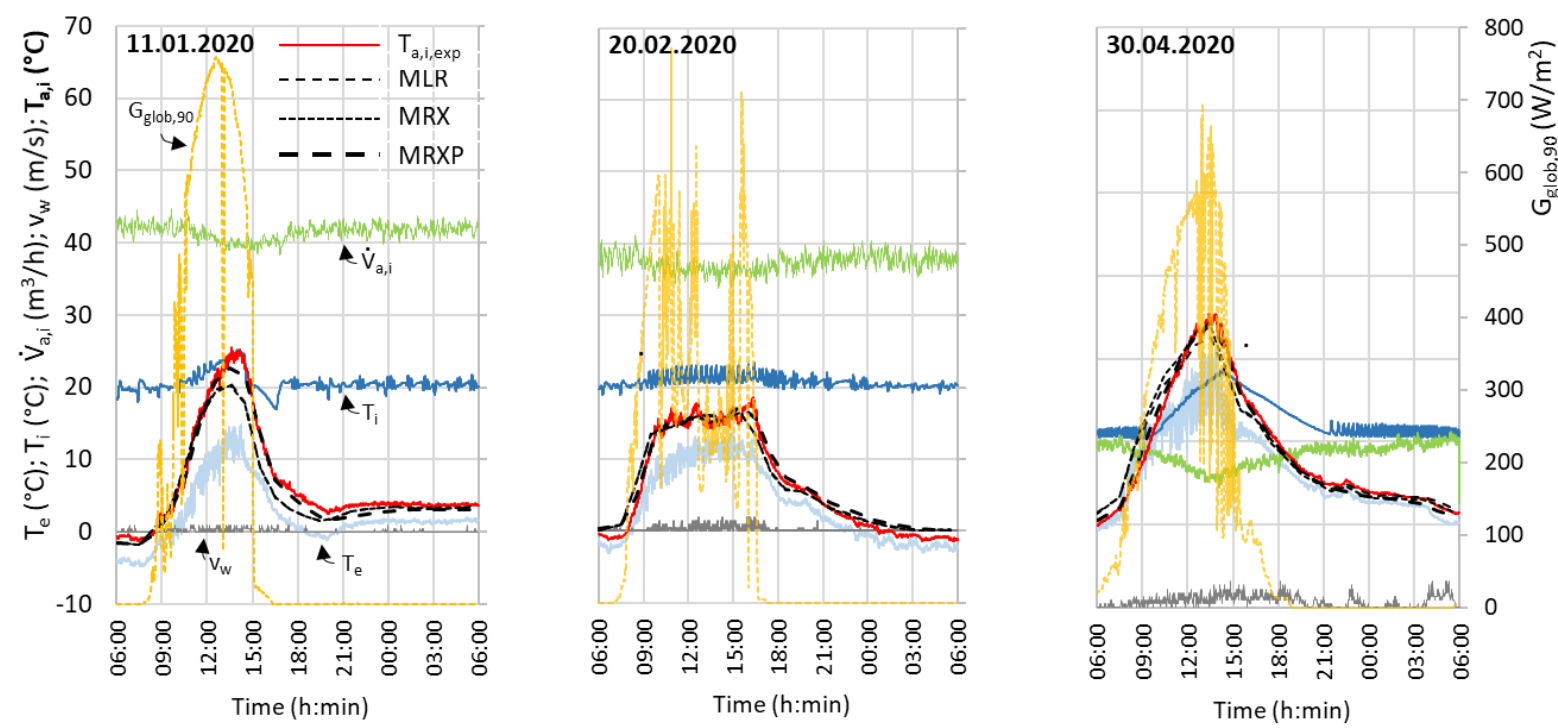

Fig. 12. Experimental data and prediction of the air temperature on the outlet of the ventilated air gap modeled with the MLR, MRX, and MRXP models for three selected days

\section{Table 1}

Statistical metric and regression coefficient in MRXP regression models of $\mathrm{E}_{\mathrm{PV}}, \dot{\mathrm{q}}_{\mathrm{i}}, \dot{\mathrm{Q}}_{\mathrm{a}, \mathrm{i}}$ and $\mathrm{T}_{\mathrm{a}, \mathrm{i}}$

\begin{tabular}{lccccc}
\hline $\begin{array}{l}\dot{q}_{i} \\
\left(\mathrm{Wh} / \mathrm{m}^{2} \mathrm{~h}\right)\end{array}$ & $\mathrm{R}^{2}$ & $\mathrm{RMSE}$ & $\mathrm{NMBE}$ & $\mathrm{CV}(\mathrm{RMSE})$ & \\
\hline & $(-)$ & $(-)$ & $(\%)$ & $(\%)$ & \\
\hline $\mathrm{x}$ & 0.95 & 2.52 & -2.0 & 58.2 & \\
& $G_{g l o b, 90}$ & $\left(T_{i}-T_{e}\right)$ & $\dot{V}_{a}$ & $v_{w}$ & $G_{g l o b, 90} \cdot \dot{V}_{a}$ \\
& $\left(\mathrm{~W} / \mathrm{m}^{2}\right)$ & $(\mathrm{K})$ & $\left(\mathrm{m}^{3} / \mathrm{h}\right)$ & $(\mathrm{m} / \mathrm{s})$ & $(\mathrm{Wm} / \mathrm{h}$ \\
\hline & $\mathrm{a}_{1, \mathrm{j}}$ & $\mathrm{a}_{2, \mathrm{j}}$ & $\mathrm{a}_{3, \mathrm{j}}$ & $\mathrm{a}_{4, \mathrm{j}}$ & $\mathrm{b}_{1}$ \\
& & & & &
\end{tabular}




\begin{tabular}{lrrrrr}
\hline $\mathrm{j}=0$ & -0.00859 & -0.3074 & -0.045 & -0.7866 & 0.0003 \\
1 & 0.00795 & 0.29107 & & & \\
2 & 0.01718 & & & & \\
3 & 0.0087 & & & & \\
4 & 0.00653 & & & & \\
5 & & -0.65728 & & & \\
\hline
\end{tabular}

\begin{tabular}{lccccc}
\hline $\begin{array}{l}\text { EPV } \\
(\mathrm{Wh} / \mathrm{h})\end{array}$ & $\mathrm{R}^{2}$ & $\mathrm{RMSE}$ & $\mathrm{NMBE}$ & $\mathrm{CV}(\mathrm{RMSE})$ \\
& $(-)$ & $(-)$ & $(\%)$ & $(\%)$ & \\
\hline $\mathrm{X}$ & 0.99 & 0.48 & -0.5 & 7.7 & \\
& $G_{g l o b, 90}$ & $T_{e}$ & $\dot{V}_{a}$ & $v_{w}$ & $G_{g l o b, 90} / T_{e}$ \\
& $\left(\mathrm{~W} / \mathrm{m}^{2}\right)$ & $\left({ }^{\circ} \mathrm{C}\right)$ & $\left(\mathrm{m}^{3} / \mathrm{h}\right)$ & $(\mathrm{m} / \mathrm{s})$ & $\left(\mathrm{W} / \mathrm{m}^{2 \circ} \mathrm{C}\right)$ \\
\hline & $\mathrm{a}_{1, \mathrm{j}}$ & $\mathrm{a}_{2, \mathrm{j}}$ & $\mathrm{a}_{3, \mathrm{j}}$ & $\mathrm{a}_{4, \mathrm{j}}$ & $\mathrm{C}_{1}$ \\
\hline $\mathrm{j}=0$ & 0.05177 & -0.01523 & 0.00039 & 0.0948 & 0.00438 \\
1 & -0.00269 & & & & \\
\hline
\end{tabular}

\begin{tabular}{lcccccc}
\hline $\begin{array}{l}\mathrm{T}_{\mathrm{a}, \mathrm{i}} \\
\left({ }^{\circ} \mathrm{C}\right)\end{array}$ & $\mathrm{R}^{2}$ & $\mathrm{RMSE}$ & $\mathrm{NMBE}$ & $\mathrm{CV}(\mathrm{RMSE})$ & & \\
\hline & $(-)$ & $(-)$ & $(\%)$ & $(\%)$ & & \\
\hline $\mathrm{x}$ & 0.99 & 0.67 & -0.01 & 5.6 & & \\
& $G_{g l o b, 90}$ & $T_{e}$ & $\dot{V}_{a}$ & $v_{w}$ & $T_{i}$ & $G_{g l o b}, 90 \cdot \dot{V}_{a}$ \\
& $\left(\mathrm{~W} / \mathrm{m}^{2}\right)$ & $\left({ }^{\circ} \mathrm{C}\right)$ & $\left(\mathrm{m}^{3} / \mathrm{h}\right)$ & $(\mathrm{m} / \mathrm{s})$ & $\left({ }^{\circ} \mathrm{C}\right)$ & $(\mathrm{Wm} / \mathrm{h})$ \\
\hline & $\mathrm{a}_{1, \mathrm{j}}$ & $\mathrm{a}_{2, \mathrm{j}}$ & $\mathrm{a}_{3, \mathrm{j}}$ & $\mathrm{a}_{4, \mathrm{j}}$ & $\mathrm{a}_{4, \mathrm{j}}$ & $\mathrm{b}_{1}$ \\
\hline $\mathrm{j}=0$ & 0.0146 & 0.38867 & -0.01746 & -0.3179 & 0.1259 & -0.0001 \\
1 & 0.007566 & 0.27375 & & & & \\
2 & & & & & & \\
3 & & 0.17497 & & & & \\
\hline
\end{tabular}

\begin{tabular}{lcccccc}
\hline$\dot{Q}_{a}$ & $\mathrm{R}^{2}$ & $\mathrm{RMSE}$ & $\mathrm{NMBE}$ & $\mathrm{CV}(\mathrm{RMSE})$ & & \\
$\left(\mathrm{Wh} / \mathrm{m}^{2} \mathrm{~h}\right)$ & $(-)$ & $(-)$ & $(\%)$ & $(\%)$ & & \\
\hline & 0.92 & 9.72 & 0.7 & 28.3 & & \\
\hline $\mathrm{x}$ & $G_{g l o b, 90}$ & $T_{e}$ & $\dot{V}_{a}$ & $v_{w}$ & $T_{i}$ & $G_{g l o b, 90} \cdot T_{e}$ \\
& $\left(\mathrm{~W} / \mathrm{m}^{2}\right)$ & $\left({ }^{\circ} \mathrm{C}\right)$ & $\left(\mathrm{m}^{3} / \mathrm{h}\right)$ & $(\mathrm{m} / \mathrm{s})$ & $\left({ }^{\circ} \mathrm{C}\right)$ & $\left(\mathrm{W}^{\circ} \mathrm{C} / \mathrm{m}^{2}\right)$ \\
\hline & $\mathrm{a}_{1, j}$ & $\mathrm{a}_{2, \mathrm{j}}$ & $\mathrm{a}_{3, \mathrm{j}}$ & $\mathrm{a}_{4, \mathrm{j}}$ & $\mathrm{a}_{4, \mathrm{j}}$ & $\mathrm{b}_{1}$ \\
\hline $\mathrm{j}=0$ & 0.1679 & -7.938 & 0.2286 & -5.633 & 0.7563 & $-0,0019$ \\
1 & 0.08284 & 3.8363 & & & & \\
2 & 0.0168 & & & & & \\
3 & & 2.196 & & & & \\
4 & -0.00602 & & & & & \\
\hline
\end{tabular}




\section{Case studies}

The overall energy balance of the prototype s- $\tau$ BIPV/T façade structure was evaluated for selected locations of office buildings: Stockholm (ST; 59.33 ${ }^{\circ}, 18.06^{\circ}, \mathrm{DD}_{20} 4180 \mathrm{Kday} / \mathrm{an}$ ), Ljubljana (LJ; $46.05^{\circ}, 14.51^{\circ}, \mathrm{DD}_{20} 3100 \mathrm{Kday} / \mathrm{an}$ ), and Zurich (ZU; 47.36 $\left.{ }^{\circ}, 8.55^{\circ}, \mathrm{DD}_{20} 3280 \mathrm{Kday} / \mathrm{an}\right)$ using previously developed regression models. Meteorological data from Typical Reference Year (TRY) [49] was used as inputs in hour-to-hour evaluation. The observation periods were adjusted to the local climate by selecting the first and the last days in the heating period according to the average outdoor air temperature above $10^{\circ} \mathrm{C}$. Overall energy balances of two conventional façades were done: one with thermal transmittance equal to the composite façade wall (U $1.027 \mathrm{~W} / \mathrm{m}^{2} \mathrm{~K}$, ("a" in Fig. 13) and the second with a thermally insulated façade with a thermal transmittance of $U 0.300 \mathrm{~W} / \mathrm{m}^{2} \mathrm{~K}$ ("b" in Fig. 13). For those two façades, transmission heat losses $Q_{i}$ were determined by applying the sol-air temperature on the hourly time step basis. The absorptivity of solar radiation 0.3 and long-wavelength radiation 0.9 of the outer surface were assumed. The transmission heat losses in the case of s- $\tau$ BIPV/T façade structures were determined using a $\mathrm{q}_{\mathrm{i}}$ approximation model. Ventilation heat losses caused by natural ventilation in the case of façade wall structures were added, assuming a constant air flow rate of supply air $\left(60 \mathrm{~m}^{3} / \mathrm{h}\right)$ during working hours (8:00-17:00). In the case of the s- $\tau$ BIPV/T, two options were analyzed (i.e., series and parallel operation modes). In this way, the reference area of the façade structure in all cases was $1 \mathrm{~m}^{2}$. In both cases, a $\mathrm{T}_{\mathrm{a}, \mathrm{i}}$ regression model was implemented.

The results of seasonal energy balances are shown in Fig. 13. All energy figures are normalized to $1 \mathrm{~m}^{2}$ of the façade structure and are determined per year (= heating season). The first column on the graphs shows transmission heat losses of the opaque façade wall structures $\left(\mathrm{Q}_{\mathrm{i}}\right)$ determined on the basis of the static thermal transmittance (reference case "a" $1.027 \mathrm{~W} / \mathrm{m}^{2} \mathrm{~K}$ and "b" $0.300 \mathrm{~W} / \mathrm{m}^{2} \mathrm{~K}$ ). The values incorporate solar gains through the opaque wall, which reduce heat losses by $8 \mathrm{kWh} / \mathrm{m}^{2}$ (LJ) to 12 $\mathrm{kWh} / \mathrm{m}^{2}(\mathrm{ST})$ in case of reference wall and $3 \mathrm{kWh} / \mathrm{m}^{2}(\mathrm{LJ})$ to $5 \mathrm{kWh} / \mathrm{m}^{2}$ (ST) in the case of the thermally insulated wall.

The decrease of transmission heat losses of s- $\tau$ BIPV/T structures can be seen in all analyzed cases as the consequence of the lower thermal transmittance and increased solar gains through the opaque wall structure. The impact of lowered thermal transmittance is shown in Fig. 13 as Q' ${ }_{\Delta \mathrm{U}}$ with values that correspond to local degree-days. There are only informative values, because they are not included separately in overall energy balance. Nevertheless, they are not accounted for in the determination of the solar efficiency $\eta_{\text {sol }}$ of the s- $\tau$ BIPV/T structures. While comparing s- $\tau$ BIPV/T structures with the reference façade wall, a significant decrease of transmission heat losses can be seen for all locations: between $\sim 25 \%$ (ST, $\mathrm{ZU}$ ) to $33 \%$ (LJ) with additional decreases of 1 to $5 \%$ in the case of serial connection due to the higher temperature of the air in the ventilation gap in this case.

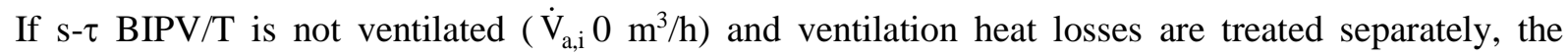
weighted energy balance (sum of $\mathrm{Q}_{\mathrm{i}}+\mathrm{E}_{\mathrm{PV}, \mathrm{w}}$ ) is lower than the transmission heat losses of the thermal insulated façade wall. In case of Ljubljana, the structure is self-sufficient regarding weighted energy $\left(\mathrm{Q}_{\mathrm{i}}+\mathrm{E}_{\mathrm{PV}, \mathrm{w}}=-98+100.3>0 \mathrm{kWh} / \mathrm{m}^{2} \mathrm{an}\right)$, which indicates the high potential of such multifunctional solutions for the energy renovation of buildings. Decreases of ventilation heat losses correspond with diurnal heat recovery efficiency and contribute the most to the overall efficiency of s- $\tau$ BIPV/T.

Electricity production differs according to the solar energy potential received by south-orientated façade structures in the observed period: in Stockholm $\mathrm{H}_{\text {glob,90 }}$ is $505 \mathrm{kWh} / \mathrm{m}^{2}$, in Zurich $433 \mathrm{kWh} / \mathrm{m}^{2}$, and in Ljubljana $397 \mathrm{kWh} / \mathrm{m}^{2}$. Values differ because of the climate and length of the heating period. The amount of electricity produced in the observed period $\mathrm{E}_{\mathrm{PV}}$ is shown in Fig. 13 and is determined, taking into account the PC cell packing factor $(60 \%)$. The ratio of the average efficiency of PV cells to the reference one is between 0.92 ( $\mathrm{ZU}$, parallel ventilation mode) and 0.88 ( $\mathrm{LJ}$, serial ventilation mode). No losses in strings and electronic devices are taken into account in the presented energy balances. 
Solar utilization efficiency $\eta_{\text {sol }}$ is highest for Ljubljana $\left(\eta_{\text {sol }}\right.$ is $51.6 \%$ for parallel and $63.0 \%$ for serial ventilation mode and lowest in Zurich (43.7\% and 50.4\%). In addition to local solar radiation, the $\eta_{\text {sol }}$ depends on the predicted time of solar energy utilization for preheating of air for ventilation (daily 8:00 to 17:00). High values of $\eta_{\text {sol }}$ are also the consequence of the utilization of the ambient heat at temperatures of outdoor air above indoor air temperatures. It was assumed that occasionally high temperatures of ventilation air (up to $35^{\circ} \mathrm{C}$ ) will not cause thermal discomfort in the reference office, due to the low ventilation air flow rate.

The overview of total energy balance has shown that prototype s- $\tau$ BIPV/T enables a reduction of energy needs from $40 \%$ (ST, ZU) to $46.6 \%$ (LJ) in parallel ventilation mode and by 43.5 (ZU), 46\% (ST) and $55.3 \%$ in Ljubljana, in the case of serial configuration. The decrease is between $6 \%$ (ST) to $8.7 \%$ (LJ) higher in the case of serial ventilation mode, which also indicates that the additional s- $\tau$ BIPV/T in serial configuration will improve energy balance and increase solar energy utilization.
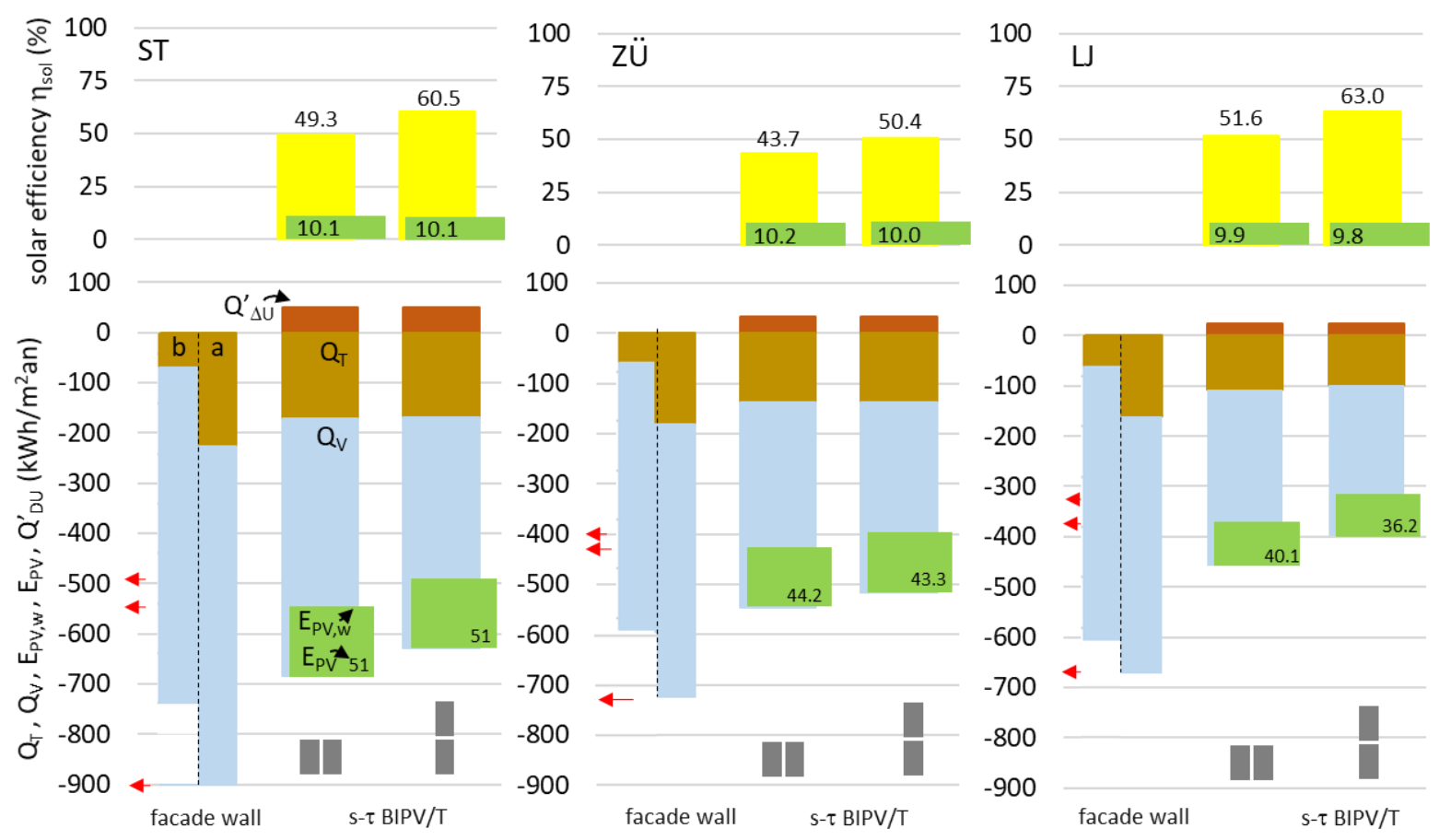

Fig. 13. Energy balance of the south-orientated prototype s- $\tau$ BIPV/T façade structure in parallel and serial operation in office buildings over the heating period in Stockholm (left), Zurich (middle) and Ljubljana (right); energy balance of reference composite ("a") and thermally insulated façade wall ("b") in a naturally ventilated building is shown; the green boxes represent weighted electricity, while figures in the green boxes represent the amount of electricity produced in the observed period; values in the green boxes at the top represent the area-weighted average efficiency of PC cells in the observed period.

\section{Conclusion}

In this paper, holistic approach procedures including the design, experimental evaluation, and the developing and validation of diurnal and dynamic regression models of the energy performance of a prototype of a semi-transparent building-integrated photovoltaic-thermal façade structure (BIPV/T) are shown. The starting point for the design of the façade structure followed the requirements of low-energy and sustainable buildings: higher energy efficiency, improved living comfort, and on-site energy production.

The novelty of the research is in the simultaneous optimization of the structure design that enables the highest increase in building performance. To fulfil these tasks, the packing factor of photovoltaic cells 
in glazed BIPV structure, the convection heat transfer in double side heated ventilated air gap, and latent heat storage on BIPV and building envelope structures was optimized. The research also reveals new findings because of some specificities of the developed structure such as: thick non-solar glass BIPV module, heat transfer in a chessboard layout of phase change material (PCM) inserts on BIPV module and the ratio of absorbed solar radiation on boundaries of air cavity. The optimization also takes into account the properties of office buildings, the type of building with high potential for BIPV, and energy demand during the heating season. In the research, several methods, such as computational fluid dynamics modeling, in-situ experimental investigation, and statistical modeling, were used.

The main findings regarding the design of semi-transparent BIPV/T façade structure are that optimal PV cell packing factor is $60 \%$, that PCM inserts in the shape of photovoltaic cells installed on the inner surface of the BIPV module have a minor impact on the efficiency only in the warmer climate conditions (Ljubljana) while no positive effect was observed for other climate conditions (Zurich, Stockholm). In contrast, PCM layer on building envelope lower the dynamic response of the structure, expressed by diurnal dynamic thermal transmittance: from $0.96 \mathrm{~W} / \mathrm{m}^{2} \mathrm{~K}$ at low daily solar radiation to $0.40 \mathrm{~W} / \mathrm{m}^{2} \mathrm{~K}$ at $2200 \mathrm{Wh} / \mathrm{m}^{2}$ day and to $0.20 \mathrm{~W} / \mathrm{m}^{2} \mathrm{~K}$ at $4000 \mathrm{Wh} / \mathrm{m}^{2}$ day. Different dynamic regression models were developed for all energy efficiency indicators. A statistical evaluation showed that multiple regression models with interactions and past values can predict dynamic response with sufficient accuracy. These models can be integrated into the dynamic thermal response computer models, which allows the designers to analyze the energy needs of buildings in different climate conditions and at different modular semi-transparent BIPV/T structure configurations, as demonstrated in the case study. From the case study, it can be seen that the energy needs of the semi-transparent BIPV/T structure can be reduced by $40 \%$ to $55 \%$ depending on local climate and ventilation mode, in comparison to the façade structure without BIPV. The solar energy utilization ranges from $44 \%$ to $63 \%$, while the photovoltaic cells operate with an all-season factor 0.88 to 0.92 of reference efficiency.

In future work, research could be extended to the summer period to propose the best possibilities for overheating protection; nevertheless, at this moment, reverse ventilation of air gaps is assumed to be an adequate measure, taking into account the higher incident angle of solar irradiance. Also, the dynamic regression models of energy performance indicators for arbitrarily orientated façades and for other types of buildings could help designers of sustainable buildings.

Acknowledgments: The authors acknowledge the financial support from the Slovenian Research Agency (research funding No. P2-0233 (C)).

\section{References}

[1] The Paris Agreement; United Nations Framework Convention on Climate Change, UN, 2020.

[2] The European Green Deal; Communication from the Commission to the European Parliament, the European Council, the Council, the European Economic and Social Committee and the Committee of Regions; EC, Brussels, 2019.

[3] Directive (EU) 2018/844 of the European Parliament and of the Council of 30 May 2018 amending Directive 2010/31/EU on the energy performance of buildings and Directive 2012/27/EU on energy efficiency; EU Brussels, 2018.

[4] Saretta E, Caputo P, Frontini F. A review study about energy renovation of building facades with BIPV in urban environment. Sustain Cities Soc 2019;44:343-355.

https://doi.org/10.1016/j.scs.2018.10.002.

[5] Solar skins: an opportunity for green cities; European Technology \& Innovation Platform and Solar Power Europe; Brussels 2019. 
[6] Young TC, Jeehwan K, Hongsik P, Byungha S. Building energy performance evaluation of building integrated photovoltaic (BIPV) window with semi-transparent solar cells. Appl Energ 2014;129:217-227. https://doi.org/10.1016/j.apenergy.2014.04.106.

[7] Defaix PR, van Sark WGJHM, Worrell E, de Visser E. Technical potential for photovoltaics on buildings in the EU-27. Sol Energy 2012;86:2644-2653.

http://dx.doi.org/10.1016/j.solener.2012.06.007.

[8] Shukla AK, Sudhakar K, Baredar P. Recent advancement in BIPV product technologies: A review. Energ Buildings 2017;140:188-195. http://dx.doi.org/10.1016/j.enbuild.2017.02.015.

[9] Zhang T, Tan Y, Yang H, Zhang X. The application of air layers in building envelopes: A review. Appl Energ 2016;165:707-734. http://dx.doi.org/10.1016/j.apenergy.2015.12.108.

[10] Biyik E, Araz M, Hepbasli A, Shahrestani M, Yao R, Shao L, Essah E, Oliveira AC, del Caño T, Rico E, Lechón JL, Andrade L, Mendes A, Baver Y. A key review of building integrated photovoltaic (BIPV) systems. Eng Sci Tech, Int J 2017;20:833-858. http://dx.doi.org/10.1016/j.jestch.2017.01.009.

[11] Xu L, Luo K, Yu B, Li Z, Huang S. Study of a hybrid BIPV/T solar wall system. Energy 2020; 193:116578. https://doi.org/10.1016/j.energy.2019.116578.

[12] Pereira R, Aelenei L. Optimization assessment of the energy performance of a BIPV/T-PCM system using Genetic Algorithms. Renew Energ 2019;137:157-166.

https://doi.org/10.1016/j.renene.2018.06.118.

[13] Koentges M., Kurtz S., Packard C., Jahn U., Berger K.A., Kato K., Friesen T., Iseghem M.; Review of Failures of Photovoltaics Modules Report IEA-PVPS T13-01:2014; Institute Fur Solarenergieforschung GmbH, D, 2014.

[14] Peng J, Lu L, Yang H, Ma T. Comparative study of the thermal and power performance of a semi-transparent photovoltaics façade under different ventilation modes. Appl Energ 2015;138:572583. http://dx.doi.org/10.1016/j.apenergy.2014.10.003.

[15] Kaiser AS, Zamora B, Mazón R, García JR, Vera F. Experimental study of cooling BIPV modules by forced convection in the air channel. Appl Energ 2014;135:88-97.

http://dx.doi.org/10.1016/j.apenergy.2014.08.079.

[16] Liu L, Kan Y, Gao K, Wang J, Zhao M, Chen H et al. Graphdiyne Derivative as Multifunctional Solid Additive in Binary Organic Solar Cells with 17.3\% Efficiency and High Reproductivity. Adv Mater 2020;32,1907604. DOI: 10.1002/adma.201907604.

[17] Gao K, Xu B, Hong C, Shi X, Liu H, Li X et al. Di-Spiro-Based Hole-Transporting Materials for Highly Efficient Perovskite Solar Cells. Adv Energy Mater 2018; 8:1800809. DOI:

10.1002/aenm.201800809

[18] Gao K, Li L, Lai T, Xiao L, Huang Y, Huang F et al. Deep Absorbing Porphyrin Small Molecule for High-Performance Organic Solar Cells with Very Low Energy Losses. J Am Chem Soc 2015;137:7282-7285. DOI: $10.1021 /$ jacs.5b03740

[19] Gao K, Zhu Z, Xu B, Jo SB, Kan Y, Peng X et al. Highly Efficient Porphyrin-Based OPV/Perovskite Hybrid Solar Cells with Extended Photoresponse and High Fill Factor. Adv Mater 2017;29:1703980. DOI: 10.1002/adma.201703980

[20] Xu S, Liao W, Huang J, Kang J. Optimal PV cell coverage ratio for semi-transparent photovoltaics on office building facades in central China. Energ Buildings 2014;77:130-138. http://dx.doi.org/10.1016/j.enbuild.2014.03.052.

[21] Yang T, Athienitis AK. Experimental investigation of a two-inlet air-based building integrated photovoltaic/thermal (BIPV/T) system. Appl Energ 2015;159:70-79.

http://dx.doi.org/10.1016/j.apenergy.2015.08.048. 
[22] Hu Z, He W, Ji J, Hu D, Lv S, Chen H, Shen Z. Comparative study on the annual performance of three types of building integrated photovoltaic (BIPV) Trombe wall system. Appl Energ 2017;194:8193. http://dx.doi.org/10.1016/j.apenergy.2017.02.018.

[23] Zhang C, Wang J, Li L, Gang W. Dynamic thermal performance and parametric analysis of a heat recovery building envelope based on air-permeable porous materials. Energy 2019;189:116361. https://doi.org/10.1016/j.energy.2019.116361.

[24] Fantucci S, Serra V, Perino M. Dynamic insulation systems: experimental analysis on a parietodynamic wall. Enrgy Proced 2015;78:549-554. https://doi.org/10.1016/j.egypro.2015.11.734.

[25] Smith JC, Forster PM, Crook R. Global analysis of photovoltaic energy output enhanced by phase change material cooling. Appl Energ 2014;126:21-28.

http://dx.doi.org/10.1016/j.apenergy.2014.03.083.

[26] Omara AAM, Abuelnuor AAA. Trombe walls with phase change materials: A review. Energy Storage 2020;e123. https://doi.org/10.1002/est2.123.

[27] Indartono YS, Suwono A, Pratama FY. Improving photovoltaics performance by using yellow petroleum jelly as phase change material. Int J Low-Carbon Tech 2016;11:333-337.

https://doi:10.1093/ijlct/ctu033.

[28] Kant K, Pitchumani R, Shukla A, Sharma A. Analysis and design of air ventilated building integrated photovoltaic (BIPV) system incorporating phase change materials. Energ Convers Manage 2019;196:149-164. https://doi.org/10.1016/j.enconman.2019.05.073.

[29] Čurpek J, Čekon M. Climate response of a BIPV façade system enhanced with latent PCM based thermal energy storage. Renew Energ 2020;152:368-384.

https://doi.org/10.1016/j.renene.2020.01.070.

[30] Japs E., Sonnenrein G., Krauter S., Vrabac J.; Experimental study of phase change materials for photovoltaic modules: Energy performance and economic yield for the EPEX spot market. Sol Energy140 51-59, 2016. doi.org/10.1016/j.solener.2016.10.48.

[31] Aelenei L, Pereira R, Gonçalves H, Athienitis A. Thermal performance of a hybrid BIPV-PCM: modeling, design and experimental investigation. Enrgy Proced 2014;48:474-483.

[32] Trigo-Gonzalez M, Batlles FJ Alonso-Montesinos, J, Ferrada P, del Sagrado J, Martínez-Durban M, Cortes M, Portillo C, Marzo A. Hourly PV production estimation by means of an exportable multiple linear regression model. Renew Energ 2019;135:303-312.

https://doi.org/10.1016/j.renene.2018.12.014.

[33] Assoa YB, Mongibello L, Carr A, Kubicek B, Machado M, Merten J, Misara S, Roca F, Sprenger W, Wagner M, Zamini S, Baenas T, Malbranche P. Thermal analysis of a BIPV system by various modelling approaches. Sol Energy 2017;155:1289-1299.

http://dx.doi.org/10.1016/j.solener.2017.07.066.

[34] Domjan S, Petek L, Arkar C, Medved S. Experimental Study on Energy Efficiency of MultiFunctional BIPV Glazed Façade Structure during Heating Season. Energies 2020;13:2772. doi:10.3390/en13112772

[35] Union Glass, S.r.i., Union Glass High-Technology Glass; http://unionglass.it/index.php (accessed on 15th January 2019)

[36] DuPont, 2012. DuPont Energain - A thermal mass solution that's ready to make its mark, DuPont, Luxemburg.

[37] Kuznik F, Virgone J. Experimental assessment of s phase change material for wall building use. Appl Energ 2009;86:2038-2046. https://doi.org/10.1016/j.apenergy.2009.01.004. 
[38] ASHRAE 62.1-2019 - Ventilation for Acceptable Indoor Air Quality (ANSI Approved); ASHRAE, USA, 2019.

[39] Energy Performance of Buildings - Ventilation of Buildings - Part 1: Indoor Environmental Input Parameters for Design and Assessment of Energy Performance of Buildings Addressing Indoor Air Quality, Thermal Environment, Light and Acoustics; EN 16798-1:2019; CEN; Brussels, Belgium, 2019.

[40] Medved S, Begelj Ž, Domjan S, Šuklje T, Černe B, Arkar C. The dynamic thermal response model and energy performance of multi-layer glass and BIPV facade structures. Energ Buildings 2019;188-189:239-251. https://doi.org/10.1016/j.enbuild.2019.02.017.

[41] Concentration, Heat and Momentum Limited (CHAM), UK, 2019.

[42] Energy Performance of Buildings - Indicators for partial EPB requirements related to thermal energy balance and fabric features - Part 1: Overview of options; EN ISO 52018-1:2017; ISO, 2017.

[43] Dash PK, Gupta NC. Effect of Temperature on Power Output from Different Commercially available Photovoltaic Modules. Int J Eng Res Appl 2015;51:148-151.

[44] Goncalves JE van Hooff T, Saelens D. A physics-based high-resolution BIPV model for building performance simulations. Sol Energy 2020;204,585-599.

https://doi.org/10.1016/j.solener.2020.04.057.

[45] ANSI/ASHRAE. ASHRAE Guideline 14: measurement of energy and demand savings; 2014.

[46] Fabrizio E, Monetti V. Methodologies and Advancements in the Calibration of Building Energy Models. Energies 2015;8,2548-2574. doi:10.3390/en8042548.

[47] Domjan S, Medved S, Černe B, Arkar C. Fast Modelling of nZEB Metrics of Office Buildings Built with Advanced Glass and BIPV Facade Structures. Energies 2019;12:e3194. doi:10.3390/en12163194

[48] Ciulla G, D’Amico A. Building energy performance forecasting: A multiple linear regression approach. Appl Energy 2019;253:e113500. https://doi.org/10.1016/j.apenergy.2019.113500.

[49] Meteonorm - Global meteorological database for solar energy and applied climatology Version 40: edition 2000 Software and data on CD_ROM (ENET-9932704-1). Switzerland. 